\title{
Heparan Sulfate Proteoglycans and Viral Attachment: True Receptors or Adaptation Bias?
}

\author{
Valeria Cagno ${ }^{1, *}$, Eirini D. Tseligka ${ }^{1}$, Samuel T. Jones ${ }^{2}$ and Caroline Tapparel ${ }^{1}$ \\ 1 Department of Microbiology and Molecular Medicine, University of Geneva Medical School, 1205 Geneva, \\ Switzerland \\ 2 School of Materials, University of Manchester, Manchester M13 9PL, UK \\ * Correspondence: valeria.cagno@unige.ch
}

Received: 17 June 2019; Accepted: 29 June 2019; Published: 1 July 2019

\begin{abstract}
Heparan sulfate proteoglycans (HSPG) are composed of unbranched, negatively charged heparan sulfate (HS) polysaccharides attached to a variety of cell surface or extracellular matrix proteins. Widely expressed, they mediate many biological activities, including angiogenesis, blood coagulation, developmental processes, and cell homeostasis. HSPG are highly sulfated and broadly used by a range of pathogens, especially viruses, to attach to the cell surface. In this review, we summarize the current knowledge on HSPG-virus interactions and distinguish viruses with established HS binding, viruses that bind HS only after intra-host or cell culture adaptation, and finally, viruses whose dependence on HS for infection is debated. We also provide an overview of the antiviral compounds designed to interfere with HS binding. Many questions remain about the true importance of these receptors in vivo, knowledge that is critical for the design of future antiviral therapies.
\end{abstract}

Keywords: viral attachment receptor; heparan sulfate proteoglycans; HSPG; syndecans; glypicans; viral adaptation; intra-host adaptation; tropism; broad-spectrum antivirals; viral binding

\section{Structure and Synthesis of Heparan Sulfate Proteoglycans}

Heparan Sulfate Proteoglycans (HSPG) are composed of a core protein covalently linked to glycosaminoglycan (GAG) chains formed by unbranched sulfated anionic polysaccharides, known as heparan sulfates (HS) (Figure 1). In addition to HS, other GAGs include chondroitin sulfates, dermatan sulfates, keratan sulfates, and hyaluronic acids.

The majority of HSPG are anchored in the plasma membrane of almost all eukaryotic cells, except for perlecan, agrin, and collagen XVII, which are present in the extracellular matrix (ECM) [1].

Syndecans and glypicans (Figure 1) are the two main classes of membrane-anchored HSPG. Syndecans are encoded by 4 different genes and represent the most abundant transmembrane HSPG. Their core protein is composed of an extracellular domain, a single transmembrane domain, and a short cytoplasmic domain that interacts with the cell cytoskeleton. Glypicans are encoded by 6 different genes and are anchored in the cell membrane via glycosylphosphatidylinositol (GPI).

The synthesis of HSPG is initiated through the attachment of the first tetrasaccharide (i.e., xylose, galactose, galactose, glucuronic acid) to a serine residue (Ser) of the core protein (Figure 2) and the subsequent addition of $\mathrm{N}$-acetyl glucosamine (GlcNAc) and glucuronic acid (GlcA). Five different glycotransferases, termed exostosins (EXT1, EXT2, EXTL1, EXTL2, EXTL3), mediate these attachments. The $\mathrm{N}$-acetyl group of GlcNAc is then replaced by a sulfate group by $4 \mathrm{~N}$-deacetylase/ $\mathrm{N}$-sulfotransferases (NDST1, NDST2, NDST3, NDST4). The subsequent step involves the epimerization of GlcA to iduronic acid (IduA) by glucuronyl C5-epimerase (GCLA C5 EPI). Finally, O-sulfotransferases (OST), i.e., 2-OST, 
6-OST, and 3-OST, further modify the HSPG [2]. As a result, the organs of the human body contain different isoforms of HSPG with various saccharide compositions and sulfation patterns $[3,4]$.

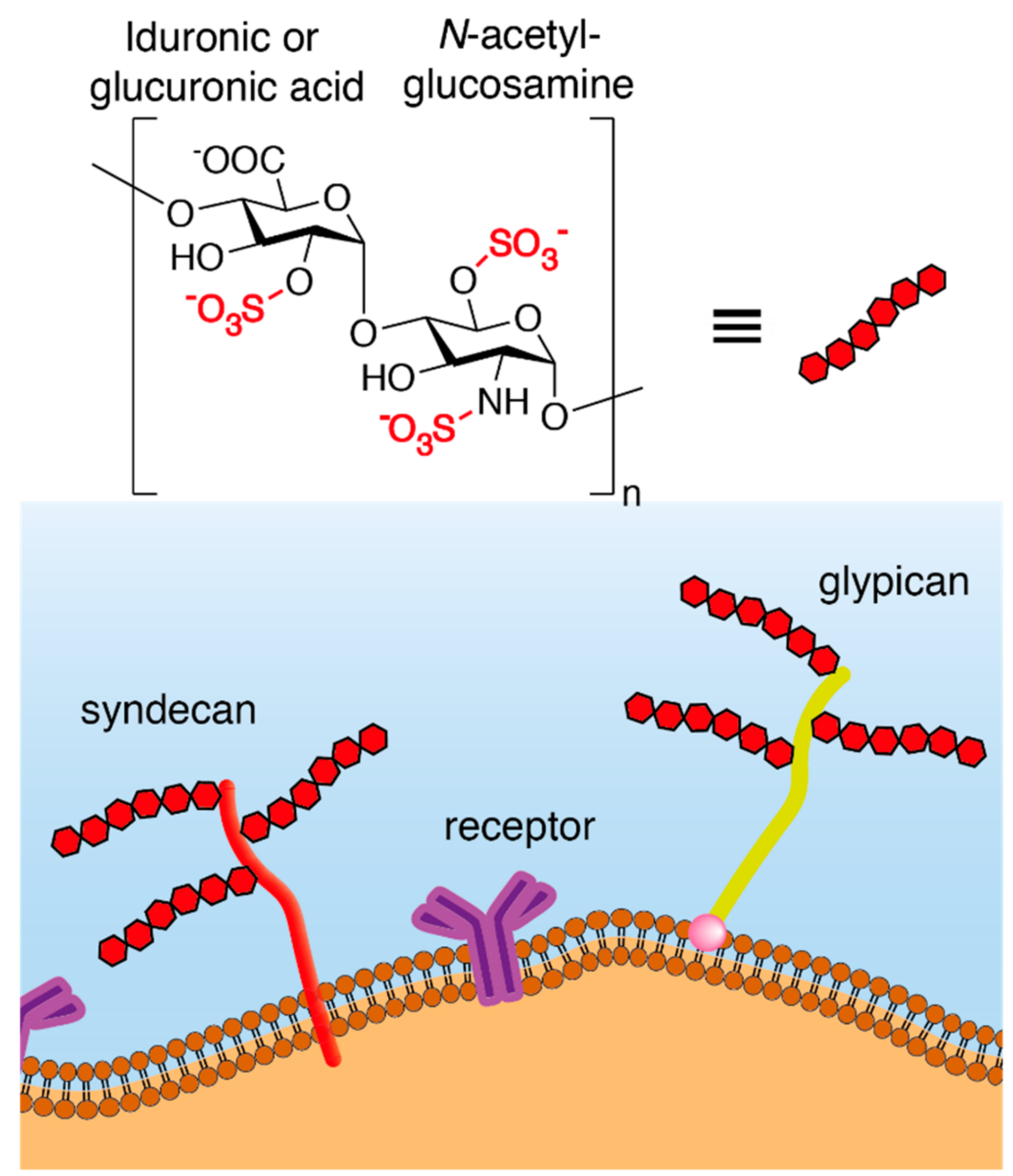

Figure 1. Schematic structure of syndecans and glypicans, the two HSPG chiefly involved in virus infection. HSPG typically consist of a core protein and GAG chains. The core protein of syndecans is composed of an extracellular domain, a single transmembrane domain, and a short cytoplasmic domain that interacts with the cytoskeleton. Glypicans are GPI-anchored HSPG. The GAG chain is composed of unbranched anionic polysaccharides composed of repeating disaccharide units formed by sulfated uronic acid and hexosamine residues.

Several enzymes are involved in the degradation of HSPG, in particular heparanase-1, which is involved in physiological and pathological roles [5]. Similar enzymes are expressed also by bacteria and used as a tool to modify HSPG on the cell surface to investigate involvement in viral infection. 


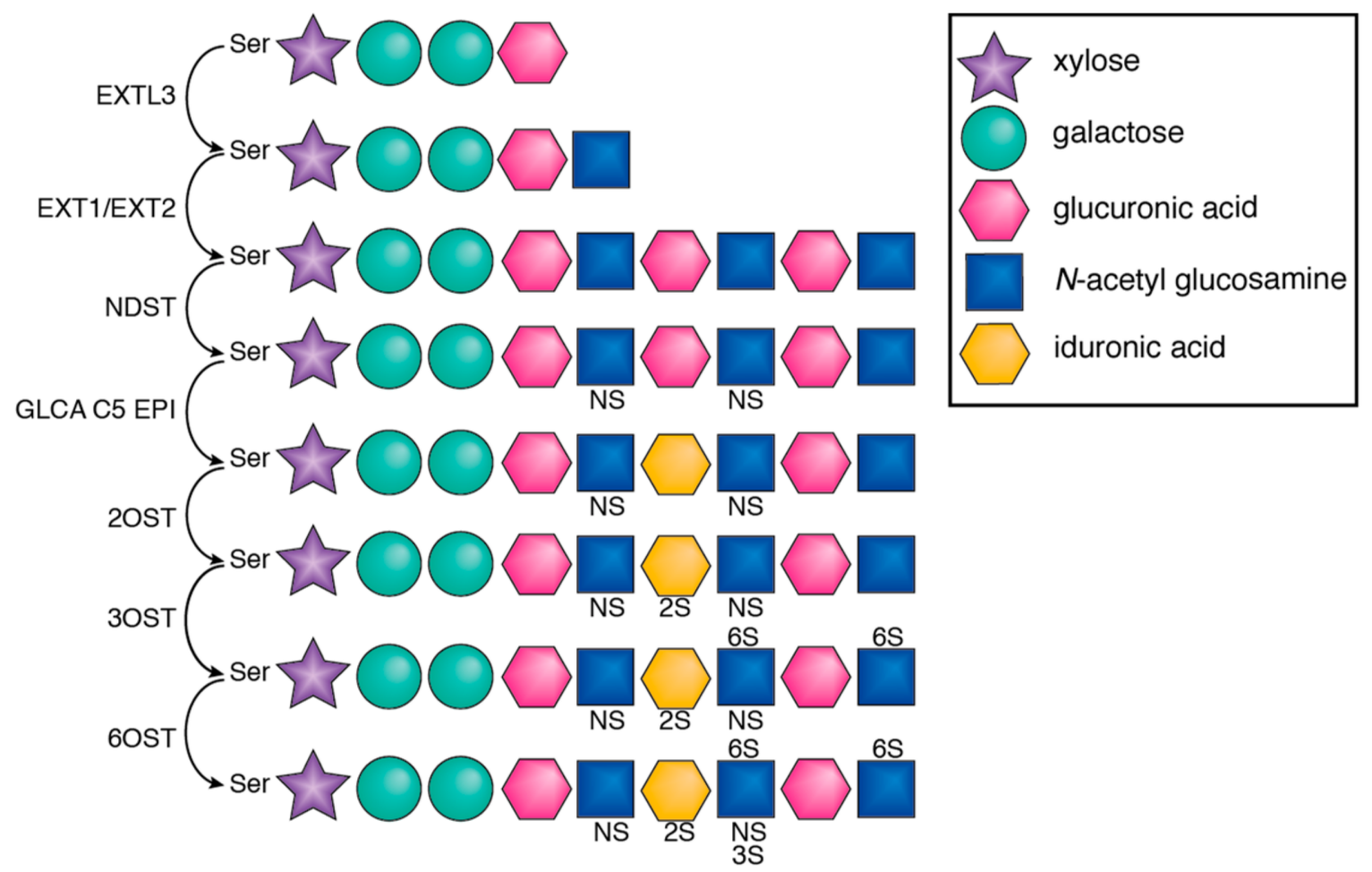

Figure 2. HS synthesis pathway. The glycans are attached to the protein core through a serine linker. After the addition of different sugars, $\mathrm{O}$ - and $\mathrm{N}$-sulfotransferases further modify the side chain conferring the negative charges.

\section{Physiological Functions of Heparan Sulfate Proteoglycans}

HSPG are conserved among vertebrates and invertebrates and have multiple functions (Figure 3). As components of the ECM, they contribute to basal membrane organization and mediate cell adhesion and motility. As part of secretory vesicles (serglycin in particular), they ensure the correct functioning of the packed content (i.e., proteases or matrix proteins). At the cell surface, HSPG bind to cytokines, chemokines, growth factors, and morphogens, preventing their degradation, thus creating temporary storage sites or gradients of morphogens important in development. Expressed at the cell surface, they also serve as endocytosis receptors, and thereby regulate the lysosomal degradation of extracellular molecules and provide nutrients to cells. Moreover, they are involved in the endocytosis of cellular receptors. They mediate the transcellular transport of chemokines across endothelial cells. They also serve as co-receptors of fibroblast growth factor (FGF) and FGF receptor in both cis (if expressed on the same cell) or trans (if expressed on different cells). They mediate intracellular signaling or intracellular stress through proteolytic shedding of syndecans. They have an important role in development and in maintaining stem cell niches.

More detailed descriptions of HSPG physiological, pathological, and morphological functions are beyond the aim of this review and can be found in $[1,4,6,7]$. 

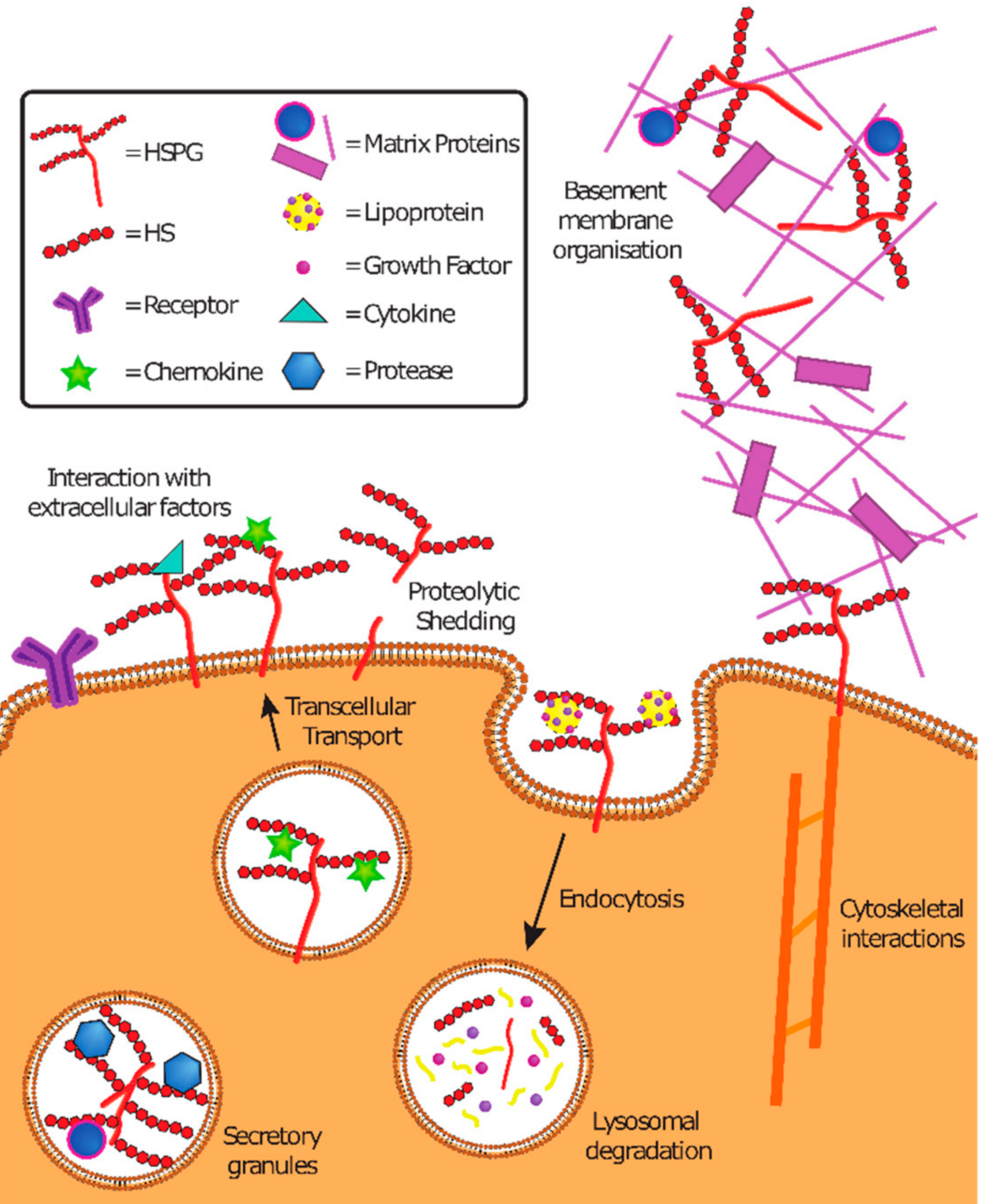

Figure 3. Functions of HSPG. HSPG in the ECM contribute to basement membrane organization. HSPG expressed on the cells mediate interactions with extracellular factors, play a role in endocytosis and lysosomal degradation and transcellular transport, and can be shed in response to stress after proteolytic cleavage. Adapted with permission from [7].

\section{Heparan Sulfate Proteoglycans As Viral Receptors}

In mammals, HSPG are ubiquitously expressed by most cell types. Due to the heavily sulfated GAG chains, they present a global negative charge that can interact electrostatically with the basic residues of viral surface glycoproteins or viral capsid proteins of non-enveloped viruses. Viruses exploit these weak interactions to increase their concentration at the cell surface and augment their chances of binding a more specific entry receptor [8]. In rare cases, HSPG serve directly as entry receptors, as described for herpes simplex virus (HSV)-1 [9]. HSPG-dependent viruses can be grouped in distinct categories, and Table 1 lists examples of each category. 
Table 1. Classification of viruses according to their HSPG dependence.

\begin{tabular}{|c|c|c|c|c|c|}
\hline \multicolumn{6}{|c|}{ HSPG Dependence } \\
\hline $\begin{array}{c}\text { Proven on Natural } \\
\text { Isolates }\end{array}$ & \multicolumn{2}{|c|}{ Proven on Laboratory Strains } & \multirow{2}{*}{$\begin{array}{c}\text { From Cell Culture Adaptation } \\
\begin{array}{c}\text { Foot and mouth disease } \\
\text { virus }[12]\end{array}\end{array}$} & \multirow{2}{*}{$\begin{array}{c}\text { From Human Intra-Host } \\
\text { Adaptation } \\
\begin{array}{c}\text { John Cunningham } \\
\text { polyomavirus [13] }\end{array}\end{array}$} & \multirow{2}{*}{$\begin{array}{c}\text { Under Debate } \\
\begin{array}{c}\text { Respiratory syncytial } \\
\text { virus [14-16] }\end{array}\end{array}$} \\
\hline Herpes simplex virus [9] & Cytomegalovirus [10] & $\begin{array}{l}\text { Human herpes virus-8 (Kaposi } \\
\text { sarcoma herpes virus) [11] }\end{array}$ & & & \\
\hline Dengue virus [17] & Pseudorabies virus [18] & Human papillomavirus $[19,20]$ & $\begin{array}{l}\text { Venezuelan equine encephalitis } \\
\text { virus [21] }\end{array}$ & Enterovirus $71[22,23]$ & Parainfluenza virus 3 [24-27] \\
\hline Echovirus 5 [28] & Merkel cell polyomavirus [29] & Hepatitis C virus [30] & Sindbis virus $[31,32]$ & & $\begin{array}{c}\text { Human } \\
\text { metapneumovirus }[14,33,34]\end{array}$ \\
\hline Echovirus 6 [35] & $\begin{array}{l}\text { Hepatitis B virus/hepatitis } \\
\text { Delta virus }[36,37]\end{array}$ & Adeno-associated virus 2 [38] & Semliki forest virus [32] & & Zika virus [39-42] \\
\hline \multirow[t]{12}{*}{$\begin{array}{c}\text { North American eastern } \\
\text { equine encephalitis } \\
\text { virus [43] }\end{array}$} & Vaccinia virus $[44,45]$ & $\begin{array}{l}\text { Human immunodeficiency } \\
\text { virus [46-48] }\end{array}$ & Rhinovirus C15 [49] & & Adenovirus 5 [50-52] \\
\hline & Adenovirus $2[50,51]$ & Filoviruses $[53,54]$ & Rhinovirus 8 [55] & & Coronavirus NL63 [56,57] \\
\hline & Norovirus genogroup II [58] & Akabane virus [59] & Rhinovirus 89 [60] & & \\
\hline & Schmallenberg virus [59] & Rift valley fever virus $[61,62]$ & Coxsackie virus B3 [63] & & \\
\hline & Rabies virus [64] & Rhinovirus 54 [65] & Yellow fever virus [66] & & \\
\hline & $\begin{array}{l}\text { Swine vesicular disease } \\
\text { virus [67] }\end{array}$ & Enterovirus $71[68]$ & $\begin{array}{c}\text { Japanese encephalitis } \\
\text { virus [69-71] }\end{array}$ & & \\
\hline & $\begin{array}{c}\text { Theiler murine } \\
\text { encephalomyelitis virus [72] }\end{array}$ & Coxsackie virus A9 [73] & West Nile virus [70] & & \\
\hline & Human parechovirus 1 [73] & Hendra and Nipah viruses [74] & Tick-borne encephalitis virus [75] & & \\
\hline & $\begin{array}{l}\text { Porcine reproductive and } \\
\text { respiratory syndrome virus [76] }\end{array}$ & $\begin{array}{l}\text { Human T cell leukemia virus } \\
\text { type } 1[77]\end{array}$ & Coronavirus group 1 [57] & & \\
\hline & Porcine circovirus 2 [78] & Hepatitis E virus [79] & Coronavirus OC43 [57] & & \\
\hline & & & Chikungunya virus $[80,81]$ & & \\
\hline & & & $\begin{array}{l}\text { Murray Valley encephalitis } \\
\text { virus [71] }\end{array}$ & & \\
\hline
\end{tabular}

Viruses in bold are discussed in detail in the following sections. 


\section{Viruses for Which Heparan Sulfate Proteoglycans Dependence Has Been Proven for Laboratory and Natural Isolates}

Here we describe the HSPG dependency of HSV, human papillomavirus (HPV), and dengue virus (DENV). We selected these viruses because numerous publications support the interaction, including experiments with clinical isolates and/or in vivo data.

\subsection{Herpes Simplex Virus}

HSV belongs to the Herpesviridae family that includes large, enveloped, double-stranded DNA (dsDNA) viruses whose manifestations range from asymptomatic infections or mild mucocutaneous lesions on the lips, cornea, genitals, or skin to more severe, even life-threatening infections, such as encephalitis and disseminated infections in neonates or immunocompromised hosts. HSV-1 causes mainly herpes labialis and is transmitted by intimate oral contact, while HSV-2 causes herpes genitalis and is transmitted by sexual intercourse. Following primary infection of the genital or oral mucosa, HSV establishes latent infections in neurons of the sensory ganglia, from which it may reactivate and cause recurrent lesions at the site of primary infection [82]. Currently, no vaccine is available, but active antivirals, such as acyclovir, which interfere with viral DNA synthesis, exist [83].

Both HSV-1 and HSV-2 use HSPG to attach to the cell surface. The absence of HSPG expression does not totally abolish the infection rate, but decreases it significantly, as the virus rarely binds directly its entry receptor [84]. Two viral surface glycoproteins, gB and gC, first interact with HSPG. In particular, HSV-1 interacts with the HSPG-rich filopodia-like structures on primary conjunctival epithelial cells [85]. In neurons, this interaction enables the virus to move along protrusions, a process referred to as "viral surfing," and reach the cellular body, where its entry receptors are expressed. A specific interaction between $\mathrm{gD}$ and different receptors [nectin-1 or nectin-2 (members of the immunoglobulin family), HVEA (herpesvirus entry mediator, a member of the tumor necrosis factor $[\mathrm{TNF}]$ proteins) $[9,84,86]$ mediates the entry. The receptors used differ depending on the cell type. Interestingly, 3O-HS (3-O-sulfated HS, a type of HSPG) is sufficient to mediate HSV-1 attachment and fusion in primary corneal fibroblasts, where nectin-1 and HVEA are not expressed [87]. Moreover, a soluble form of 3O-HS can mediate HSV-1 infection in CHO-K1, a cell line to which the virus can attach but not enter [88]. After binding with the entry receptors, gD undergoes a conformational change that allows viral fusion. The surface glycoproteins $\mathrm{gH}$ and $\mathrm{gL}$ also play a fundamental role in this process, forming a fusion complex, together with $\mathrm{gD}$ and $\mathrm{gB}$, necessary for release of the tegument proteins and viral DNA into the host cell [89]. Interestingly, recent studies have highlighted that HSV induces heparanase overexpression in infected cells to facilitate detachment and spreading. This mechanism prevents virus trapping at the cell surface through receptor binding, as does the cleavage of sialic acid by influenza neuraminidase [90,91].

Several sulfated molecules (i.e., heparin, carrageenan, dendrimers, nanoparticles, and others) inhibit HSV infection, further supporting the role of HS in viral attachment [27,92-94] (Table 2). 
Table 2. Compounds showing broad-spectrum activity by interfering with virus-HSPG interaction.

\begin{tabular}{|c|c|c|c|}
\hline Virus & Molecule & Virus & Molecule \\
\hline \multirow{10}{*}{ HSV-1 } & Heparin [27] & \multirow{10}{*}{ HSV-2 } & Heparin [27] \\
\hline & Carrageenans [27] & & Carrageenans [27] \\
\hline & Cellulose sulfate [95] & & Cellulose sulfate [95] \\
\hline & PRO $2000[96,97]$ & & PRO $2000^{\text {a }}[96,97]$ \\
\hline & SB105-A10 dendrimer [98] & & VivaGel (SPL7013) a [99] \\
\hline & Sulfated K5 derivatives [100] & & SB105-A10 dendrimer [98] \\
\hline & Agmatine-derived polymers [93] & & Sulfated K5 derivatives [100] \\
\hline & MUS:OT * nanoparticles [92] & & Agmatine-derived polymers ${ }^{\mathrm{b}, \mathrm{c}}[93]$ \\
\hline & \multirow{2}{*}{ DSTP27 ** $[94]$} & & MUS:OT * nanoparticles ${ }^{b}$ [92] \\
\hline & & & DSTP $27{ }^{* *}[94]$ \\
\hline \multirow{5}{*}{ HCMV } & Heparin [10] & \multirow{5}{*}{ DENV2 } & Heparin [101] \\
\hline & SB105-A10 dendrimer [98] & & Carrageenans [102] \\
\hline & Sulfated K5 derivatives [103] & & Sulfated K5 derivatives [101] \\
\hline & Agmatine-derived polymers [104] & & MUS.OT * nanonarticles [92] \\
\hline & DSTP $27 * *$ [94] & & \\
\hline \multirow{8}{*}{ HIV } & Heparin [27] & \multirow{8}{*}{ HPV } & Heparin ${ }^{c}[105]$ \\
\hline & Carrageenans $^{\mathrm{d}}[27,106,107]$ & & Carrageenans ${ }^{c, e}[105,108,109]$ \\
\hline & Cellulose sulfate ${ }^{\mathrm{d}}[95,107,110]$ & & Cellulose sulfate [111] \\
\hline & PRO $2000^{d}[96,107]$ & & SB105-A10 dendrimer [112] \\
\hline & VivaGel (SPL7013) a [99] & & Sulfated K5 derivatives [113] \\
\hline & SB105-A10 dendrimer ${ }^{\mathrm{b}}$ [114] & & Agmatine-derived polymers [115] \\
\hline & Sulfated K5 derivatives [116] & & MUS:OT* nanoparticles [92] \\
\hline & DSTP27 ** [94] & & DSTP27 ** [117] \\
\hline \multirow{6}{*}{ RSV } & Heparin [118] & \multirow{6}{*}{ HMPV } & Heparin [119] \\
\hline & SB105-A10 dendrimer ${ }^{\mathrm{f}}[16]$ & & Carrageenans [33] \\
\hline & Sulfated K5 derivatives ${ }^{\mathrm{f}}$ [15] & & SB105-A10 dendrimer ${ }^{\mathrm{f}}$ [33] \\
\hline & MUS:OT * nanoparticles ${ }^{c}$ [92] & & \\
\hline & Agmatine-derived polymers [104] & & Sulfated $\mathrm{K} 5$ derivatives ${ }^{\mathrm{f}}$ [33] \\
\hline & DSTP27 ** [94] & & \\
\hline \multirow{3}{*}{ EBOV } & Heparin [53] & \multirow{3}{*}{ MARV } & Heparin [53] \\
\hline & Carrageenans [53] & & Carrageenans [53] \\
\hline & SB105-A10 dendrimer [53] & & SB105-A10 dendrimer [53] \\
\hline VV & Heparin [45] & EV-A71 & Carrageenans $[23,120]$ \\
\hline
\end{tabular}

\subsection{Human Papillomavirus}

Human papillomavirus (HPV) is a small, non-enveloped dsDNA virus in the Papillomaviridae family. It infects the epithelial cells of the skin and the anogenital or oropharyngeal mucosa, causing benign or malignant neoplastic lesions. HPVs are the most common sexually transmitted viruses and are subdivided into low-risk types, which can cause low-grade cervical lesions and genital warts, and high-risk types, which cause cervix carcinoma, as well as anus, vulva, vagina, penis, and oropharynx cancers. Vaccines are available but there is no approved antiviral. 
Several types of HPV, such as HPV-16, HPV-18, HPV-31, HPV-45, HPV-6, and also bovine papillomaviruses, are dependent on HSPG both in vitro and in vivo. It is believed that all papillomaviruses depend on HSPG for their initial attachment; however, due to its oncogenic potential and prevalence, HPV-16 is the serotype whose entry is most studied [20,105,112,115].

HPV starts its infectious cycle from the basal membrane of the vaginal mucosa, exploiting abrasions or lesions in the epithelium. The first contact is mediated mainly by HSPG expressed on the cellular surface of basal keratinocytes or on the ECM. A role for laminin-332 (formerly termed laminin-5) in the attachment has also been proposed [121-123]. Syndecan-1 plays a major role in this initial attachment, due to its expression on epithelial cells and its overproduction during wound healing [124]. The dependence on HSPG has been demonstrated not only in vitro, but also in vivo, in mice pretreated topically with heparinase III, or treated at the time of infection with heparin and then infected with HPV-16, HPV-5, and HPV-31. In presence of these treatments, a significant decrease in infection was observed [125]. The critical residues for the interaction between HSPG and HPV have been mapped as Lys278 and Lys361 on the exposed portion of the capsid protein L1 [126].

After contact with HSPG, the HPV capsid undergoes conformational changes assisted by extracellular cyclophilin B [127] and cleavage of the L2 capsid protein by furin [128]. This leads to the loss of affinity for HSPG and binding to different secondary receptors. Identification of the internalization receptor is ongoing, but $\alpha 6$ integrins, epidermal growth factor receptor (EGFR) and the tetraspanins family may be involved [129]. The entry kinetics of HPV appear to be asynchronous and slower than for the majority of other viruses, but the cause is still not fully understood $[20,111,130]$. Some research suggests that it may be linked to the cell cycle phase or the engagement of multiple receptors [129]. Subsequently, the virus is internalized through endocytosis, but there are contradictory reports on different HPV types and cells. However, entry of HPV-16 -18 and -31 pseudovirions in epithelial cells is independent of clathrin and caveolae $[129,131]$ suggesting a common endocytic pathway for all HPV.

Several HSPG-mimicking or -interacting molecules such as small molecules, dendrimers, carrageenan, heparin, and nanoparticles $[92,105,112,113,115,117]$ have proven to be effective for preventing HPV infection (Table 2). A carrageenan-based gel was tested in the Carraguard phase IIB clinical trial, where the treated arm showed enhanced protection when compared with the placebo arm. However, despite the promising effectiveness of the microbicide against HPV in the phase IIB clinical trial, no phase III clinical trial was performed [132]. This may be linked to the failure of such trials with similar compounds against HIV (Table 2).

\subsection{Dengue Virus}

Dengue virus (DENV) is an enveloped, positive-sense single-stranded RNA (ssRNA+) virus of the Flaviviridae family, which is composed of 4 distinct serotypes (DENV1, DENV2, DENV3, DENV4). Billions of people live in areas at risk of dengue transmission, and approximately 390 million DENV infections are reported yearly, leading to 25,000 deaths [133]. The virus is mainly transmitted by Aedes mosquito bites. Infected individuals can be asymptomatic or display dengue fever, a self-limiting disease. However, especially after secondary infections by a different DENV serotype, the virus can cause dengue hemorrhagic fever (DHF) and dengue shock syndrome (DSS), both of which can lead to death.

The first demonstration of DENV binding to HSPG was reported in 1997, where highly sulfated liver-derived HS, as well as heparin, were shown to inhibit DENV2. Moreover, the alteration of GAG expression or sulfation on cells reduced DENV infectivity, as demonstrated through treatment of Vero cells with heparinase I and III or sodium chlorate (a sulfation inhibitor) and through infection in psg-D677 and psg-A745 CHO cell lines, which lack HSPG synthesis [134]. The HSPG dependence has also been demonstrated by competition experiments with numerous sulfated molecules (see Table 2) $[92,101,102,134]$. The interaction site with HSPG has been mapped subsequently to domain III of the dengue envelope (E) protein, on an external loop region rich in surface basic residues [135]. Over 
time, numerous papers have been published on the interaction between the E protein and HSPG in human endothelial, liver, and animal cell lines [136-138]. It is unclear if there is also an interaction with HSPG in insect cell lines (C6/36) $[139,140]$. Moreover, to exclude any effect linked to cell adaptation, DENV pseudoparticles produced with the sequences of $\mathrm{E}$ and pre-matrix (prM) proteins of viruses never passaged in cells have been shown to bind HSPG and heparin in a manner comparable to that of viruses extensively passaged in cell lines [17].

In human cell lines, HSPG are well proven to be the first attachment receptors, followed by more specific interactions with one of the known entry receptors such as dendritic cell-specific intercellular adhesion molecule-3-grabbing non-integrin (DC-SIGN), the mannose receptor (MR) for macrophages, and other proteinaceous receptors [141]. The variety of receptors demonstrated to be involved in DENV entry may be related to the wide variety of tissues infected (liver, lymph node, spleen, bone marrow) [141].

\section{Viruses That Show Attachment to Heparan Sulfate Proteoglycans After Cell Adaptation}

Some viruses do not use HSPG as receptors in vivo but become HSPG-dependent after repeated passage in cell culture. Many cell lines express HSPG abundantly. Given their error-prone replication machinery, viruses can rapidly mutate. A possible outcome is an increase in the number of basic residues on their surface protein, leading to acquisition of the ability to use negatively charged GAG chains as attachment receptors. This results in improved viral fitness and the out-competing of HSPG-independent variants.

\section{Rhinoviruses and Other Picornaviruses}

Rhinoviruses (RVs) are small ssRNA+ viruses in the Enterovirus genus in the Picornaviridae family. They are the main causes of acute viral infections worldwide. In immunocompetent individuals, RVs typically induce the common cold with nasal congestion and rhinorrhea, coughing, sneezing, sore throat and malaise, and spontaneous resolution within 1-2 weeks [142]. However, RVs can also cause a wide range of complicated illnesses, such as exacerbation of asthma $[143,144]$ and of chronic obstructive pulmonary disease [145,146], pneumonia, and bronchiolitis [147], as well as chronic infections in immunocompromised hosts, with fatal outcome in some cases $[148,149]$. This group of viruses consists of numerous types that are organized into 3 species: RV-A (80 types), RV-B (32 types), and RV-C (56 types). Most RV-As and all RV-Bs bind intercellular adhesion molecule 1 (ICAM1) [150] for cell entry and belong to the major group RVs, while 11 RV-As use the low-density lipoprotein receptor family (LDL-R) and belong to the minor group RVs [151]. Some major group RVs (RV-8, -54, -89) can also use HSPG as an additional receptor $[55,60,65]$ either directly or after multiple passages in cells lacking ICAM1. For the HSPG-dependent variants, increased susceptibility to acidic $\mathrm{pH}$ and elevated temperatures suggest that the greater instability might compensate for the absence of the uncoating activity of ICAM1 and the loss of virulence in vivo [60]. The third RV species, RV-C, uses cadherin-related family member 3 (CDHR3) to infect the cell [152]. CDHR3 is specifically expressed on ciliated cells of airway epithelia, explaining why RV-Cs do not grow in standard cells [153]. However, exogenous expression of CDHR3 in HeLa cells renders the cells permissive to RV-C. Serial passages of RV-C15 in these cells leads to increased viral binding, viral yields, and stronger cytopathic effects. A mutation in the external surface of the VP1 capsid protein, T125K, was identified in the majority of the adapted viral population and was demonstrated to confer enhanced HS-mediated cell binding [49]. The adapted virus was also able to replicate in HeLa cells lacking CDHR3, although to a lower extent, as well as in primary differentiated bronchial cells.

In addition to rhinoviruses, members of the enterovirus (EV)-B species, such as Coxsackie virus B3 (CV-B3) [154], culture-adapted echoviruses, low-passage clinical echovirus 6 isolates, and echovirus 5 bind HSPG [35]. The natural receptors of CV-B3 are decay-accelerating factor (DAF) and the coxsackie adenovirus receptor (CAR), but it is possible to select, through cell adaptation, a HS-binding variant. This virus is associated with mutations in VP1 and a change of cellular tropism with lytic infection in a 
wider spectrum of cell lines as opposed to the parental strain. Similarly to CV-B3, foot-and-mouth disease virus (FMDV), a member of the Aphthovirus genus in the Picornaviridae family, also adapts easily to HS binding during tissue culture through the selection of positive charge-containing amino acids within the capsid protein. In conclusion, despite the majority of Picornaviridae family members being reported to bind other receptors, some, especially after cell culture adaptation, are able to bind HSPG.

Of note, as these viruses can become HSPG-dependent in cell lines, similar adaptations may occur during human infections to promote replication in HSPG-enriched tissues. The next paragraph highlights some examples.

\section{Viruses with Acquired Dependence on Heparan Sulfate Proteoglycans after Human Intra-Host Adaptation}

Each infected host presents a different environment that may favor the selection of new and fitter viral variants. To follow this intra-host adaptation, viral sequencing must be performed at different times and in different sites during the disease course. In the case of enterovirus 71 (EV-A71) and John Cunningham polyomavirus (JCV), the original clinical strains did not use HSPG as primary receptors, but mutant viruses binding HSPG were isolated from the central nervous system of patients.

\subsection{Enterovirus 71}

EV-A71 is a non-enveloped ssRNA+ virus in the Picornaviridae family. It is typically transmitted via the fecal-oral route, but in countries with high hygiene levels, transmission also occurs via the respiratory route [155]. EV-A71 is one of the major causative agents of the mild and self-limiting hand, foot, and mouth disease (HFMD) outbreaks in the Asia-Pacific region [6,156-158]. In rare cases, particularly in immunocompromised patients or children below 6 years old, the virus can disseminate to the central nervous system, leading to severe and fatal neurological complications [159,160]. No effective antiviral treatment is currently available for EV-A71 infections. However, the Chinese Food and Drug Administration (FDA) has approved two inactivated vaccines against the $\mathrm{C} 4$ genogroup, which is the most prevalent genogroup in these areas [161].

EV-A71 can infect cells via two entry receptors that trigger viral uncoating and RNA release in the cytoplasm: SCARB2 (scavenger receptor class B member 2), a major transmembrane lysosomal protein [162], and PSGL-1 (P-selectin glycoprotein ligand-1), which is primarily expressed on leukocytes and interacts with specific EV-A71 strains $[163,164]$. In addition, EV-A71 can use a variety of different attachment receptors such as HSPG [68], sialic acids [165], nucleolin [152,166], vimentin [140,167], and annexin II [168]. These receptors enhance viral infectivity and may contribute to viral dissemination and neurotropism.

Viral genome analysis of clinical specimens isolated directly from an immunocompromised patient with disseminated EV-A71 infection has revealed intra-host adaptation [22]. A single mutation in the VP1 capsid protein, i.e., a substitution of the neutral leucine with a positively charged arginine $\left(\mathrm{VP} 1_{\mathrm{L} 97 \mathrm{R}}\right)$, was present in the blood and the cerebrospinal fluid (CSF) and in the gastrointestinal tract, while it was absent from respiratory tract specimens of the immunocompromised patient. As opposed to the VP1 $1_{97 \mathrm{~L}}$ variant, VP1 $1_{97 \mathrm{R}}$ showed HSPG-binding ability [23] and was inhibited by highly sulfated carrageenans in Vero cells and neural cell cultures, underlining the fact that HS analogs can be promising compounds for preventing EV-A71 replication and dissemination. These data sets suggest EV-A71 adaptation in vivo towards a HS-dependent variant that promotes viral dissemination and neurotropism in an immunosuppressed patient [23].

\subsection{Polyomaviruses}

Polyomaviruses belong to the family of Polyomaviridae and are non-enveloped dsDNA viruses. These viruses persistently infect the majority of the population. The primary infection occurs in early childhood through person-to-person contact or through contaminated surfaces. However, healthy individuals do not show any signs of disease, while in immunocompromised patients, the 
viruses can reactivate and cause pathologies. Currently, no vaccines or antivirals are available for polyomaviruses [169]. The majority of these viruses can hemagglutinate erythrocytes due to their binding to sialic acid, which is exposed on gangliosides. The only member of the family reported to bind HSPG naturally is Merkel cell polyomavirus, a virus associated with a lethal skin cancer in the elderly and in the immunocompromised [170]. The virus is dependent on HSPG in the initial attachment phase, as demonstrated by the lack of binding to HSPG-deficient $\mathrm{CHO}$ cell lines and the inhibition after heparinase treatment. In a subsequent step, the virus interacts with sialic acid, which mediates entry [29].

Another member of the Polyomaviridae is JCV. In immunocompromised individuals such as AIDS patients, JCV is responsible for progressive multifocal leukoencephalopathy (PML) leading to rapid demyelination in the central nervous system, with consequent cognitive impairment and motor dysfunctions [169]. JCV receptors on cells are sialic acid residues on the lactoseries tetrasaccharide $\mathrm{C}$ (LTSc pentasaccharide) and the serotonin receptor 5-HT 2A R [171,172]. However, virus isolated from the urine of healthy subjects differs from that isolated from patients with PML in the form of mutations in the major capsid protein VP1 $[13,173]$. A recent study showed that these mutants have increased HSPG binding activity, as demonstrated by decreased ability to bind cells after heparinase treatment and increased heparin inhibition when compared to the parental non-mutated strain. These mutations and differences in binding can confer the ability to infect neural cells, which are known to express high levels of glypicans and syndecans [13].

\section{Viruses with Controversial Data on Heparan Sulfate Proteoglycans Dependence}

The actual HS dependence of some viruses is still debated due to their relatively new emergence or re-emergence, such as Zika virus (ZIKV), or to the probable lack of HSPG on their natural sites of infection, such as respiratory syncytial virus (RSV). Of note, as viral receptors are mostly investigated in cell lines with laboratory adapted viruses, some of these controversies may also be the result of in vitro adaptations.

\subsection{Respiratory Syncytial Virus}

Human RSVs are enveloped ssRNA- of the Orthopneumovirus genus in the Pneumoviridae family. They are the primary cause of bronchiolitis and pneumonia in children under 5 years of age and are also linked to respiratory complications in the immunocompromised and the elderly. It has been estimated that, in 2015, RSV caused (globally) acute lower respiratory infections in 33.1 million children aged less than 5 years, with 3.2 million hospital admissions and 59,600 deaths [174]. No vaccine is currently available, and the only approved specific treatment is palivizumab, a monoclonal antibody directed against RSV fusion (F) protein. This immunoglobulin is used only as prophylaxis and is limited to pre-term, low-weight, immunocompromised infants $[175,176]$.

RSV binding to cells involves an initial interaction between the basic amino acids present on the viral envelope proteins $G$ and F and the negatively charged HSPG [177-179]. Subsequently, the virus engages secondary receptors: nucleolin [180], ICAM1 [181], C-X3-C motif chemokine receptor 1 (CX3CR1) [182], and annexin II [183]. These interactions induce a conformational change of the $\mathrm{F}$ protein with exposure of its fusion peptide, promoting fusion of the viral envelope and the cell plasma membrane and release of the nucleocapsid in the cytoplasm [184].

Competition experiments with heparin and other sulfated molecules, enzymatic removal of HSPG from the cellular surface, as well as inhibition of sulfation have shown that RSV initial attachment to cells is HSPG-dependent $[118,177,178]$ (Table 2). However, recent studies on human airway epithelial (HAE) cultures have shown that HS have limited expression on the apical side compared to the basal side $[23,26]$, and RSV is known to infect mainly apical ciliated cells of the respiratory epithelia [14,15]. Therefore, it has been proposed that RSV can bind different receptors in cells and in HAE, where CX3CR1 is sufficient for mediating the infection $[14,185]$. 
Nonetheless, some compounds related to HSPG have also proven to be inhibitory in $\operatorname{HAE}[15,16]$ and in vivo [92] (Table 2). The CX3CR1 and HSPG binding sites are distinct but spatially close; therefore, HSPG mimetics may inhibit CX3CR1-mediated infection via steric hindrance.

To our knowledge, there has been no study in HAE with clinical isolates to investigate whether HSPG binding is linked to cellular adaptation or is a property of all RSV strains. In the latter case, this receptor may be used by the virus in vivo to infect cells expressing HSPG such as in the alveoli or in yet unidentified cells. Indeed, HAE are representative of upper respiratory tract airways, while HSPG, in particular syndecan- 1 and syndecan-4, are abundant in the alveolar epithelia [186], and RSV complications are associated with lower respiratory infections.

Alternatively, restricted HSPG expression at the apical side of HAE may also be due to artifacts linked to HAE differentiation in vitro. Immunostaining of CX3CR1 and HSPG expression in human biopsies would aid understanding the specific role of each of these receptors in RSV infection.

Moreover, the same considerations can be extended to other members of the Pneumoviridae family, particularly human metapneumovirus (HMPV), which also binds HSPG, infects ciliated cells on HAE, and whose inhibition with sulfated molecules has also been shown in HAE [33,34] (Table 2).

\subsection{Zika Virus}

ZIKV belongs to the Flaviviridae family and is an enveloped ssRNA+ virus. It has been recently associated with birth defects in South America, due to the ability of the virus to cross the placental barrier and infect the neural system of the fetus, causing microcephaly [187]. Up to 580,000 suspected cases of ZIKV were reported to PAHO (Pan American Health Organization) from January 2015 to January 2018 only in the Americas [187]. Its entry mechanism has not been fully elucidated, although due to phylogenetic similarity, it is proposed to be similar to DENV.

In a study using a surface plasmon resonance (SPR) binding assay, Kim and colleagues showed that ZIKV E protein interacts with HS and chondroitin sulfates. The authors calculated that the binding constant (Kd) is $443 \mathrm{nM}$, while that of DENV E protein is $15 \mathrm{nM}$. They ascribe this variation to the higher number of basic residues on the DENV E protein as compared to that of ZIKV [39].

However, the results of successive studies that used the full virus instead of the purified E protein did not indicate a dependence of ZIKV on HSPG. In two studies, a negatively charged molecule proved to be active against ZIKV, but not through inhibition of HSPG binding [40,41].

Tan et al. reported that suramin was effective against ZIKV; however, the infectivity of ZIKV in cell lines was not diminished after sodium chlorate wash or heparinase I/III treatment, nor was it possible to observe any interaction between the virus and heparin-Sepharose beads. Through molecular dynamics simulation, the authors evidenced a strong interaction between suramin and ZIKV helicase, possibly explaining the inhibitory activity [40].

In a second study, heparin was poorly effective against ZIKV, and mainly through inhibition of the caspase III and apoptotic pathways, protecting the cells from cell death rather than having effects on viral adhesion to the cell [41].

An additional study showed that HSPG are present in mosquitoes and in different human anatomical sites known to be efficiently infected by ZIKV. Nevertheless, when the virus was pre-incubated with different heparin variants, not only there was no protection, but the viral titer was also increased [188].

Further research, in which a clinical isolate was serially passaged in Vero cells, identified the L307F mutation in domain III of the ZIKV E protein, with possible but not verified involvement in the attachment to cell HSPG, enhancing viral infectivity in combination with a mutation (M220V) in nonstructural protein 1 (NS1) [189].

These controversial results suggest that ZIKV, although closely related to DENV, is not dependent on HSPG, with the exclusion of the SPR study, where only the ZIKV E protein was used.

Contradictory results have also emerged from studies in which host genes necessary for viral replication were identified. ZIKV, as well as DENV, requires the expression of EXT1 and NDST1, two 
enzymes of the HS biosynthetic pathway [42]. However, another study showed that ZIKV binding to cells was not affected by inactivation of the SLC35B2 (solute carrier family 35 member B2) gene, which is involved in the sulfation of HSPG. The same results were obtained for the glycosyltransferases B3GAT3 (beta-1,3-glucuronyltransferase 3) and B4GALT7 (beta-1,4-galactosyltransferase 7), while the inactivation of the 3 genes was effective in preventing DENV binding. However, ZIKV intracellular RNA in knockout cells was reduced at early time points, and subsequently increased, as compared to the wild-type cells, with an effect related to the inhibition of cell death [190].

Therefore, the pleiotropic effects of HSPG on the ZIKV cell cycle warrant further investigation.

\section{Heparan Sulfate Proteoglycans Binding and Virulence}

HSPG are highly expressed in almost all human tissues. Viruses that can bind this receptor are thus expected to have broader tropism. Indeed, some reports support an association between HSPG binding and virulence, while on the contrary, others show an inverse correlation between usage of this receptor and virulence or dissemination abilities. HSPG binding promotes HIV neurovirulence by allowing the infection of endothelial cells that do not express CD4 and facilitating the crossing of the blood-brain barrier [191]. Increased neurovirulence was also described for a natural isolate of North American eastern equine encephalitis virus compared to a mutant with impaired HSPG binding ability [43]. The same observation was made for a strain of Sindbis virus with a glutamate-to-histidine substitution in the E protein as compared to its non-mutated counterpart [192]. As discussed above, a HSPG-binding EV-A71 mutant was isolated from the blood and CSF of a patient with disseminated infection [23], and variants with increased numbers of positively charged amino acids in the VP1 capsid protein are also frequently isolated from patients with neurological complications [193]. Altogether, these data support an association between dissemination, neurovirulence, and HS dependency in humans.

However, several animal experiments show the opposite association. EV-A71 [194], FMDV [12], and yellow fever virus (YFV) [195] strains adapted to bind HSPG in cells are less prone to dissemination in animal models. In the same vein, after inoculation of HSPG-dependent CV-B3 [63] and DENV2 [196] variants, HSPG-independent revertants could be isolated from different sites. This link between HSPG dependency and inefficient dissemination extends to other flaviviruses (JEV [Japanese encephalitis virus], WNV [West Nile virus], MVE [Murray Valley encephalitis]) [69-71]. Finally, a recent study in a mouse model of hepatitis B virus (HBV) infection also corroborates a negative association between HSPG binding and viral spread. HBV undergoes a slow maturation process, in which the HSPG binding protein is exposed in a temperature- and time-dependent manner. Based on their observations, the authors suggested that HBV could use this process to avoid becoming trapped in the blood stream, where HSPG are highly expressed but the infection would be unproductive. With this strategy instead, the virus can reach the liver, and after binding HSPG, infect the cells via its receptor, sodium/taurocholate cotransporting polypeptide (NTCP) [197]. Nonetheless, these studies present several limitations. First, animal models are often genetically modified to support viral infections (i.e., IFN [interferon] receptor knockout or transgenic expression of the viral receptors), second, inoculated viruses are animal-adapted, and finally, the inoculation route and infectious doses used are far from natural conditions. Additional reports in more relevant models are thus necessary to aid understanding of the true impact of HSPG binding on viral pathogenesis in humans.

\section{Conclusions}

HSPG are widely distributed cellular receptors with various biological activities. These receptors are hijacked by numerous viruses to attach to host cells. This typically occurs through electrostatic interactions between the negative charges of HSPG and the basic amino acid portions of viral surface proteins. Here, we describe viruses with inherent or acquired ability to bind HSPG. A consistent amount of data supports the natural dependence of HSV, DENV, and HPV on HSPG for their attachment to the host cells. For other highly prevalent viruses such as FMDV, CV-B3, or the rhinoviruses RV-C15, RV-A8, and RV-A89, adaptation to HSPG occurs after extensive passaging in cells or in the absence of their 
primary receptor. Interestingly, some viruses such as EV-A71 and JCV can even gain HSPG-binding ability in vivo after intra-host adaptation. Finally, for other viruses such as RSV or ZIKV, HSPG binding remains controversial, and the literature contains contradictory reports. Despite extensive studies into HSPG-virus interactions, the true impact of this receptor on in vivo viral pathogenesis remains also poorly understood. In some cases, HSPG binding appears to promote dissemination and neurovirulence, while in other reports, it traps the virus and leads to attenuated infection. Additional investigations with clinical viral strains and in conditions as close as possible to native human infection will clarify these issues.

Due to their use by many distinct viruses, HSPG represent an ideal broad-spectrum antiviral target. However, several HSPG-mimicking compounds such as carrageenan, cellulose sulfate, and PRO 2000 have failed in phase III clinical trials, as their inhibitory effect was lost upon dilution in body fluids, probably leading to the release of infectious particles [107]. We recently successfully designed broad-spectrum, non-toxic antiviral nanoparticles mimicking HSPG and presenting an irreversible virucidal inhibition mechanism [92]. Additional efforts in this direction will aid the development of antiviral drugs that are effective not only on a large number of existing viruses but also on unpredictable emerging viruses.

Funding: C.T. was supported by Leenaards Foundation grant n ME10409 and Swiss National Science Foundation grant n. 310030_184777 and Sinergia grant ME11323.

Conflicts of Interest: The authors declare no conflict of interest.

\section{References}

1. Sarrazin, S.; Lamanna, W.C.; Esko, J.D. Heparan sulfate proteoglycans. Cold Spring Harb. Perspect. Biol. 2011, 3. [CrossRef] [PubMed]

2. Busse-Wicher, M.; Wicher, K.B.; Kusche-Gullberg, M. The exostosin family: Proteins with many functions. Matrix Biol. 2014, 35, 25-33. [CrossRef] [PubMed]

3. Kreuger, J.; Kjellen, L. Heparan sulfate biosynthesis: Regulation and variability. J. Histochem. Cytochem. 2012, 60, 898-907. [CrossRef] [PubMed]

4. Xu, D.; Esko, J.D. Demystifying heparan sulfate-protein interactions. Annu Rev. Biochem 2014, 83, 129-157. [CrossRef] [PubMed]

5. Bame, K.J. Heparanases: Endoglycosidases that degrade heparan sulfate proteoglycans. Glycobiology 2001, 11, 91R-98R. [CrossRef] [PubMed]

6. Bernfield, M.; Gotte, M.; Park, P.W.; Reizes, O.; Fitzgerald, M.L.; Lincecum, J.; Zako, M. Functions of cell surface heparan sulfate proteoglycans. Annu Rev. Biochem. 1999, 68, 729-777. [CrossRef] [PubMed]

7. Bishop, J.R.; Schuksz, M.; Esko, J.D. Heparan sulphate proteoglycans fine-tune mammalian physiology. Nature 2007, 446, 1030-1037. [CrossRef]

8. Rusnati, M.; Vicenzi, E.; Donalisio, M.; Oreste, P.; Landolfo, S.; Lembo, D. Sulfated K5 Escherichia coli polysaccharide derivatives: A novel class of candidate antiviral microbicides. Pharmacol. Ther. 2009, 123, 310-322. [CrossRef]

9. Shukla, D.; Liu, J.; Blaiklock, P.; Shworak, N.W.; Bai, X.; Esko, J.D.; Cohen, G.H.; Eisenberg, R.J.; Rosenberg, R.D.; Spear, P.G. A novel role for 3-O-sulfated heparan sulfate in herpes simplex virus 1 entry. Cell 1999, 99, 13-22. [CrossRef]

10. Compton, T.; Nowlin, D.M.; Cooper, N.R. Initiation of human cytomegalovirus infection requires initial interaction with cell surface heparan sulfate. Virology 1993, 193, 834-841. [CrossRef]

11. Birkmann, A.; Mahr, K.; Ensser, A.; Yaguboglu, S.; Titgemeyer, F.; Fleckenstein, B.; Neipel, F. Cell surface heparan sulfate is a receptor for human herpesvirus 8 and interacts with envelope glycoprotein K8.1. J. Virol. 2001, 75, 11583-11593. [CrossRef] [PubMed]

12. Sa-Carvalho, D.; Rieder, E.; Baxt, B.; Rodarte, R.; Tanuri, A.; Mason, P.W. Tissue culture adaptation of foot-and-mouth disease virus selects viruses that bind to heparin and are attenuated in cattle. J. Virol. 1997, 71, 5115-5123. [PubMed] 
13. Geoghegan, E.M.; Pastrana, D.V.; Schowalter, R.M.; Ray, U.; Gao, W.; Ho, M.; Pauly, G.T.; Sigano, D.M.; Kaynor, C.; Cahir-McFarland, E.; et al. Infectious Entry and Neutralization of Pathogenic JC Polyomaviruses. Cell Rep. 2017, 21, 1169-1179. [CrossRef] [PubMed]

14. Johnson, S.M.; McNally, B.A.; Ioannidis, I.; Flano, E.; Teng, M.N.; Oomens, A.G.; Walsh, E.E.; Peeples, M.E. Respiratory Syncytial Virus Uses CX3CR1 as a Receptor on Primary Human Airway Epithelial Cultures. PLoS Pathog. 2015, 11, e1005318. [CrossRef] [PubMed]

15. Cagno, V.; Donalisio, M.; Civra, A.; Volante, M.; Veccelli, E.; Oreste, P.; Rusnati, M.; Lembo, D. Highly sulfated K5 Escherichia coli polysaccharide derivatives inhibit respiratory syncytial virus infectivity in cell lines and human tracheal-bronchial histocultures. Antimicrob. Agents Chemother. 2014, 58, 4782-4794. [CrossRef] [PubMed]

16. Donalisio, M.; Rusnati, M.; Cagno, V.; Civra, A.; Bugatti, A.; Giuliani, A.; Pirri, G.; Volante, M.; Papotti, M.; Landolfo, S.; et al. Inhibition of human respiratory syncytial virus infectivity by a dendrimeric heparan sulfate-binding peptide. Antimicrob. Agents Chemother. 2012, 56, 5278-5288. [CrossRef]

17. Artpradit, C.; Robinson, L.N.; Gavrilov, B.K.; Rurak, T.T.; Ruchirawat, M.; Sasisekharan, R. Recognition of heparan sulfate by clinical strains of dengue virus serotype 1 using recombinant subviral particles. Virus Res. 2013, 176, 69-77. [CrossRef]

18. Trybala, E.; Bergstrom, T.; Spillmann, D.; Svennerholm, B.; Flynn, S.J.; Ryan, P. Interaction between pseudorabies virus and heparin/heparan sulfate. Pseudorabies virus mutants differ in their interaction with heparin/heparan sulfate when altered for specific glycoprotein C heparin-binding domain. J. Biol. Chem. 1998, 273, 5047-5052. [CrossRef]

19. Buck, C.B.; Day, P.M.; Trus, B.L. The papillomavirus major capsid protein L1. Virology 2013, 445, $169-174$. [CrossRef]

20. Giroglou, T.; Florin, L.; Schafer, F.; Streeck, R.E.; Sapp, M. Human papillomavirus infection requires cell surface heparan sulfate. J. Virol. 2001, 75, 1565-1570. [CrossRef]

21. Bernard, K.A.; Klimstra, W.B.; Johnston, R.E. Mutations in the E2 glycoprotein of Venezuelan equine encephalitis virus confer heparan sulfate interaction, low morbidity, and rapid clearance from blood of mice. Virology 2000, 276, 93-103. [CrossRef] [PubMed]

22. Cordey, S.; Petty, T.J.; Schibler, M.; Martinez, Y.; Gerlach, D.; van Belle, S.; Turin, L.; Zdobnov, E.; Kaiser, L.; Tapparel, C. Identification of site-specific adaptations conferring increased neural cell tropism during human enterovirus 71 infection. PLoS Pathog. 2012, 8, e1002826. [CrossRef] [PubMed]

23. Tseligka, E.D.; Sobo, K.; Stoppini, L.; Cagno, V.; Abdul, F.; Piuz, I.; Meylan, P.; Huang, S.; Constant, S.; Tapparel, C. A VP1 mutation acquired during an enterovirus 71 disseminated infection confers heparan sulfate binding ability and modulates ex vivo tropism. PLoS Pathog. 2018, 14, e1007190. [CrossRef] [PubMed]

24. Hendricks, G.L.; Velazquez, L.; Pham, S.; Qaisar, N.; Delaney, J.C.; Viswanathan, K.; Albers, L.; Comolli, J.C.; Shriver, Z.; Knipe, D.M.; et al. Heparin octasaccharide decoy liposomes inhibit replication of multiple viruses. Antivir. Res. 2015, 116, 34-44. [CrossRef]

25. Bose, S.; Banerjee, A.K. Role of heparan sulfate in human parainfluenza virus type 3 infection. Virology 2002, 298, 73-83. [CrossRef] [PubMed]

26. Zhang, L.; Bukreyev, A.; Thompson, C.I.; Watson, B.; Peeples, M.E.; Collins, P.L.; Pickles, R.J. Infection of ciliated cells by human parainfluenza virus type 3 in an in vitro model of human airway epithelium. J. Virol. 2005, 79, 1113-1124. [CrossRef]

27. Baba, M.; Snoeck, R.; Pauwels, R.; de Clercq, E. Sulfated polysaccharides are potent and selective inhibitors of various enveloped viruses, including herpes simplex virus, cytomegalovirus, vesicular stomatitis virus, and human immunodeficiency virus. Antimicrob. Agents Chemother. 1988, 32, 1742-1745. [CrossRef]

28. Israelsson, S.; Gullberg, M.; Jonsson, N.; Roivainen, M.; Edman, K.; Lindberg, A.M. Studies of Echovirus 5 interactions with the cell surface: Heparan sulfate mediates attachment to the host cell. Virus Res. 2010, 151, 170-176. [CrossRef]

29. Schowalter, R.M.; Pastrana, D.V.; Buck, C.B. Glycosaminoglycans and sialylated glycans sequentially facilitate Merkel cell polyomavirus infectious entry. PLoS Pathog. 2011, 7, e1002161. [CrossRef]

30. Xu, Y.; Martinez, P.; Seron, K.; Luo, G.; Allain, F.; Dubuisson, J.; Belouzard, S. Characterization of hepatitis C virus interaction with heparan sulfate proteoglycans. J. Virol. 2015, 89, 3846-3858. [CrossRef]

31. Klimstra, W.B.; Ryman, K.D.; Johnston, R.E. Adaptation of Sindbis virus to BHK cells selects for use of heparan sulfate as an attachment receptor. J. Virol. 1998, 72, 7357-7366. [PubMed] 
32. Smit, J.M.; Waarts, B.L.; Kimata, K.; Klimstra, W.B.; Bittman, R.; Wilschut, J. Adaptation of alphaviruses to heparan sulfate: Interaction of Sindbis and Semliki forest viruses with liposomes containing lipid-conjugated heparin. J. Virol. 2002, 76, 10128-10137. [CrossRef] [PubMed]

33. Klimyte, E.M.; Smith, S.E.; Oreste, P.; Lembo, D.; Dutch, R.E. Inhibition of Human Metapneumovirus Binding to Heparan Sulfate Blocks Infection in Human Lung Cells and Airway Tissues. J. Virol. 2016, 90, 9237-9250. [CrossRef] [PubMed]

34. Chang, A.; Masante, C.; Buchholz, U.J.; Dutch, R.E. Human metapneumovirus (HMPV) binding and infection are mediated by interactions between the HMPV fusion protein and heparan sulfate. J. Virol. 2012, 86, 3230-3243. [CrossRef] [PubMed]

35. Goodfellow, I.G.; Sioofy, A.B.; Powell, R.M.; Evans, D.J. Echoviruses bind heparan sulfate at the cell surface. J. Virol. 2001, 75, 4918-4921. [CrossRef] [PubMed]

36. Leistner, C.M.; Gruen-Bernhard, S.; Glebe, D. Role of glycosaminoglycans for binding and infection of hepatitis B virus. Cell Microbiol 2008, 10, 122-133. [CrossRef] [PubMed]

37. Lamas Longarela, O.; Schmidt, T.T.; Schoneweis, K.; Romeo, R.; Wedemeyer, H.; Urban, S.; Schulze, A. Proteoglycans act as cellular hepatitis delta virus attachment receptors. PLoS ONE 2013, 8, e58340. [CrossRef] [PubMed]

38. Summerford, C.; Samulski, R.J. Membrane-associated heparan sulfate proteoglycan is a receptor for adeno-associated virus type 2 virions. J. Virol. 1998, 72, 1438-1445.

39. Kim, S.Y.; Zhao, J.; Liu, X.; Fraser, K.; Lin, L.; Zhang, X.; Zhang, F.; Dordick, J.S.; Linhardt, R.J. Interaction of Zika Virus Envelope Protein with Glycosaminoglycans. Biochemistry 2017, 56, 1151-1162. [CrossRef]

40. Tan, C.W.; Sam, I.C.; Chong, W.L.; Lee, V.S.; Chan, Y.F. Polysulfonate suramin inhibits Zika virus infection. Antivir. Res. 2017, 143, 186-194. [CrossRef]

41. Ghezzi, S.; Cooper, L.; Rubio, A.; Pagani, I.; Capobianchi, M.R.; Ippolito, G.; Pelletier, J.; Meneghetti, M.C.Z.; Lima, M.A.; Skidmore, M.A.; et al. Heparin prevents Zika virus induced-cytopathic effects in human neural progenitor cells. Antivir. Res. 2017, 140, 13-17. [CrossRef] [PubMed]

42. Savidis, G.; McDougall, W.M.; Meraner, P.; Perreira, J.M.; Portmann, J.M.; Trincucci, G.; John, S.P.; Aker, A.M.; Renzette, N.; Robbins, D.R.; et al. Identification of Zika Virus and Dengue Virus Dependency Factors using Functional Genomics. Cell Rep. 2016, 16, 232-246. [CrossRef] [PubMed]

43. Gardner, C.L.; Ebel, G.D.; Ryman, K.D.; Klimstra, W.B. Heparan sulfate binding by natural eastern equine encephalitis viruses promotes neurovirulence. Proc. Natl. Acad. Sci. USA 2011, 108, 16026-16031. [CrossRef] [PubMed]

44. Lin, C.L.; Chung, C.S.; Heine, H.G.; Chang, W. Vaccinia virus envelope H3L protein binds to cell surface heparan sulfate and is important for intracellular mature virion morphogenesis and virus infection in vitro and in vivo. J. Virol. 2000, 74, 3353-3365. [CrossRef] [PubMed]

45. Chung, C.S.; Hsiao, J.C.; Chang, Y.S.; Chang, W. A27L protein mediates vaccinia virus interaction with cell surface heparan sulfate. J. Virol. 1998, 72, 1577-1585. [PubMed]

46. Connell, B.J.; Lortat-Jacob, H. Human immunodeficiency virus and heparan sulfate: From attachment to entry inhibition. Front. Immunol. 2013, 4, 385. [CrossRef] [PubMed]

47. Pomin, V.H.; Bezerra, F.F.; Soares, P.A.G. Sulfated Glycans in HIV Infection and Therapy. Curr. Pharm. Des. 2017, 23, 3405-3414. [CrossRef]

48. Patel, M.; Yanagishita, M.; Roderiquez, G.; Bou-Habib, D.C.; Oravecz, T.; Hascall, V.C.; Norcross, M.A. Cell-surface heparan sulfate proteoglycan mediates HIV-1 infection of T-cell lines. Aids Res. Hum. Retrovir. 1993, 9, 167-174. [CrossRef]

49. Bochkov, Y.A.; Watters, K.; Basnet, S.; Sijapati, S.; Hill, M.; Palmenberg, A.C.; Gern, J.E. Mutations in VP1 and 3A proteins improve binding and replication of rhinovirus C15 in HeLa-E8 cells. Virology 2016, 499, 350-360. [CrossRef]

50. Dechecchi, M.C.; Tamanini, A.; Bonizzato, A.; Cabrini, G. Heparan sulfate glycosaminoglycans are involved in adenovirus type 5 and 2-host cell interactions. Virology 2000, 268, 382-390. [CrossRef]

51. Dechecchi, M.C.; Melotti, P.; Bonizzato, A.; Santacatterina, M.; Chilosi, M.; Cabrini, G. Heparan sulfate glycosaminoglycans are receptors sufficient to mediate the initial binding of adenovirus types 2 and 5. J. Virol. 2001, 75, 8772-8780. [CrossRef] [PubMed] 
52. Zaiss, A.K.; Foley, E.M.; Lawrence, R.; Schneider, L.S.; Hoveida, H.; Secrest, P.; Catapang, A.B.; Yamaguchi, Y.; Alemany, R.; Shayakhmetov, D.M.; et al. Hepatocyte Heparan Sulfate Is Required for Adeno-Associated Virus 2 but Dispensable for Adenovirus 5 Liver Transduction In Vivo. J. Virol. 2016, 90, 412-420. [CrossRef] [PubMed]

53. Salvador, B.; Sexton, N.R.; Carrion, R., Jr.; Nunneley, J.; Patterson, J.L.; Steffen, I.; Lu, K.; Muench, M.O.; Lembo, D.; Simmons, G. Filoviruses utilize glycosaminoglycans for their attachment to target cells. J. Virol. 2013, 87, 3295-3304. [CrossRef]

54. O’Hearn, A.; Wang, M.; Cheng, H.; Lear-Rooney, C.M.; Koning, K.; Rumschlag-Booms, E.; Varhegyi, E.; Olinger, G.; Rong, L. Role of EXT1 and Glycosaminoglycans in the Early Stage of Filovirus Entry. J. Virol. 2015, 89, 5441-5449. [CrossRef] [PubMed]

55. Khan, A.G.; Pickl-Herk, A.; Gajdzik, L.; Marlovits, T.C.; Fuchs, R.; Blaas, D. Entry of a heparan sulphate-binding HRV8 variant strictly depends on dynamin but not on clathrin, caveolin, and flotillin. Virology 2011, 412, 55-67. [CrossRef]

56. Milewska, A.; Zarebski, M.; Nowak, P.; Stozek, K.; Potempa, J.; Pyrc, K. Human coronavirus NL63 utilizes heparan sulfate proteoglycans for attachment to target cells. J. Virol. 2014, 88, 13221-13230. [CrossRef]

57. De Haan, C.A.; Haijema, B.J.; Schellen, P.; Wichgers Schreur, P.; te Lintelo, E.; Vennema, H.; Rottier, P.J. Cleavage of group 1 coronavirus spike proteins: How furin cleavage is traded off against heparan sulfate binding upon cell culture adaptation. J. Virol. 2008, 82, 6078-6083. [CrossRef]

58. Tamura, M.; Natori, K.; Kobayashi, M.; Miyamura, T.; Takeda, N. Genogroup II noroviruses efficiently bind to heparan sulfate proteoglycan associated with the cellular membrane. J. Virol. 2004, 78, 3817-3826. [CrossRef]

59. Murakami, S.; Takenaka-Uema, A.; Kobayashi, T.; Kato, K.; Shimojima, M.; Palmarini, M.; Horimoto, T. Heparan Sulfate Proteoglycan Is an Important Attachment Factor for Cell Entry of Akabane and Schmallenberg Viruses. J. Virol. 2017, 91. [CrossRef]

60. Vlasak, M.; Goesler, I.; Blaas, D. Human rhinovirus type 89 variants use heparan sulfate proteoglycan for cell attachment. J. Virol. 2005, 79, 5963-5970. [CrossRef]

61. Riblett, A.M.; Blomen, V.A.; Jae, L.T.; Altamura, L.A.; Doms, R.W.; Brummelkamp, T.R.; Wojcechowskyj, J.A. A Haploid Genetic Screen Identifies Heparan Sulfate Proteoglycans Supporting Rift Valley Fever Virus Infection. J. Virol. 2016, 90, 1414-1423. [CrossRef] [PubMed]

62. De Boer, S.M.; Kortekaas, J.; de Haan, C.A.; Rottier, P.J.; Moormann, R.J.; Bosch, B.J. Heparan sulfate facilitates Rift Valley fever virus entry into the cell. J. Virol. 2012, 86, 13767-13771. [CrossRef] [PubMed]

63. Wang, Y.; Pfeiffer, J.K. Emergence of a Large-Plaque Variant in Mice Infected with Coxsackievirus B3. mBio 2016, 7, e00119. [CrossRef] [PubMed]

64. Sasaki, M.; Anindita, P.D.; Ito, N.; Sugiyama, M.; Carr, M.; Fukuhara, H.; Ose, T.; Maenaka, K.; Takada, A.; Hall, W.W.; et al. The Role of Heparan Sulfate Proteoglycans as an Attachment Factor for Rabies Virus Entry and Infection. J. Infect. Dis 2018, 217, 1740-1749. [CrossRef]

65. Khan, A.G.; Pichler, J.; Rosemann, A.; Blaas, D. Human rhinovirus type 54 infection via heparan sulfate is less efficient and strictly dependent on low endosomal pH. J. Virol. 2007, 81, 4625-4632. [CrossRef] [PubMed]

66. Fernandez-Garcia, M.D.; Meertens, L.; Chazal, M.; Hafirassou, M.L.; Dejarnac, O.; Zamborlini, A.; Despres, P.; Sauvonnet, N.; Arenzana-Seisdedos, F.; Jouvenet, N. Vaccine and Wild-Type Strains of Yellow Fever Virus Engage Distinct Entry Mechanisms and Differentially Stimulate Antiviral Immune Responses. mBio 2016, 7, e01956-01915. [CrossRef] [PubMed]

67. Escribano-Romero, E.; Jimenez-Clavero, M.A.; Gomes, P.; Garcia-Ranea, J.A.; Ley, V. Heparan sulphate mediates swine vesicular disease virus attachment to the host cell. J. Gen. Virol. 2004, 85, 653-663. [CrossRef] [PubMed]

68. Tan, C.W.; Poh, C.L.; Sam, I.C.; Chan, Y.F. Enterovirus 71 uses cell surface heparan sulfate glycosaminoglycan as an attachment receptor. J. Virol. 2013, 87, 611-620. [CrossRef]

69. Liu, H.; Chiou, S.S.; Chen, W.J. Differential binding efficiency between the envelope protein of Japanese encephalitis virus variants and heparan sulfate on the cell surface. J. Med. Virol. 2004, 72, 618-624. [CrossRef]

70. Lee, E.; Hall, R.A.; Lobigs, M. Common E protein determinants for attenuation of glycosaminoglycan-binding variants of Japanese encephalitis and West Nile viruses. J. Virol. 2004, 78, 8271-8280. [CrossRef] [PubMed]

71. Lee, E.; Lobigs, M. Mechanism of virulence attenuation of glycosaminoglycan-binding variants of Japanese encephalitis virus and Murray Valley encephalitis virus. J. Virol. 2002, 76, 4901-4911. [CrossRef] [PubMed] 
72. Upfold, N.; Ross, C.; Bishop, O.T.; Luke, G.A.; Knox, C. The generation and characterisation of neutralising antibodies against the Theiler's murine encephalomyelitis virus (TMEV) GDVII capsid reveals the potential binding site of the host cell co-receptor, heparan sulfate. Virus Res. 2018, 244, 153-163. [CrossRef] [PubMed]

73. Merilahti, P.; Karelehto, E.; Susi, P. Role of Heparan Sulfate in Cellular Infection of Integrin-Binding Coxsackievirus A9 and Human Parechovirus 1 Isolates. PLoS ONE 2016, 11, e0147168. [CrossRef] [PubMed]

74. Mathieu, C.; Dhondt, K.P.; Chalons, M.; Mely, S.; Raoul, H.; Negre, D.; Cosset, F.L.; Gerlier, D.; Vives, R.R.; Horvat, B. Heparan sulfate-dependent enhancement of henipavirus infection. mBio 2015, 6, e02427. [CrossRef]

75. Mandl, C.W.; Kroschewski, H.; Allison, S.L.; Kofler, R.; Holzmann, H.; Meixner, T.; Heinz, F.X. Adaptation of tick-borne encephalitis virus to BHK-21 cells results in the formation of multiple heparan sulfate binding sites in the envelope protein and attenuation in vivo. J. Virol. 2001, 75, 5627-5637. [CrossRef]

76. Delputte, P.L.; Costers, S.; Nauwynck, H.J. Analysis of porcine reproductive and respiratory syndrome virus attachment and internalization: Distinctive roles for heparan sulphate and sialoadhesin. J. Gen. Virol 2005, 86, 1441-1445. [CrossRef]

77. Jones, K.S.; Fugo, K.; Petrow-Sadowski, C.; Huang, Y.; Bertolette, D.C.; Lisinski, I.; Cushman, S.W.; Jacobson, S.; Ruscetti, F.W. Human T-cell leukemia virus type 1 (HTLV-1) and HTLV-2 use different receptor complexes to enter T cells. J. Virol. 2006, 80, 8291-8302. [CrossRef]

78. Misinzo, G.; Delputte, P.L.; Meerts, P.; Lefebvre, D.J.; Nauwynck, H.J. Porcine circovirus 2 uses heparan sulfate and chondroitin sulfate B glycosaminoglycans as receptors for its attachment to host cells. J. Virol. 2006, 80, 3487-3494. [CrossRef]

79. Kalia, M.; Chandra, V.; Rahman, S.A.; Sehgal, D.; Jameel, S. Heparan sulfate proteoglycans are required for cellular binding of the hepatitis E virus ORF2 capsid protein and for viral infection. J. Virol. 2009, 83, 12714-12724. [CrossRef]

80. Silva, L.A.; Khomandiak, S.; Ashbrook, A.W.; Weller, R.; Heise, M.T.; Morrison, T.E.; Dermody, T.S. A single-amino-acid polymorphism in Chikungunya virus E2 glycoprotein influences glycosaminoglycan utilization. J. Virol. 2014, 88, 2385-2397. [CrossRef]

81. Gardner, C.L.; Hritz, J.; Sun, C.; Vanlandingham, D.L.; Song, T.Y.; Ghedin, E.; Higgs, S.; Klimstra, W.B.; Ryman, K.D. Deliberate attenuation of chikungunya virus by adaptation to heparan sulfate-dependent infectivity: A model for rational arboviral vaccine design. PLoS Negl. Trop. Dis. 2014, 8, e2719. [CrossRef] [PubMed]

82. Whitley, R.; Kimberlin, D.W.; Prober, C.G. Pathogenesis and disease. In Human Herpesviruses: Biology, Therapy, and Immunoprophylaxis; Arvin, A., Campadelli-Fiume, G., Mocarski, E., Moore, P.S., Roizman, B., Whitley, R., Yamanishi, K., Eds.; Cambridge University Press: Cambridge, UK, 2007.

83. Kimberlin, D.W.; Whitley, R.J. Antiviral therapy of HSV-1 and -2. In Human Herpesviruses: Biology, Therapy, and Immunoprophylaxis; Arvin, A., Campadelli-Fiume, G., Mocarski, E., Moore, P.S., Roizman, B., Whitley, R., Yamanishi, K., Eds.; Cambridge University Press: Cambridge, UK, 2007.

84. Spear, P.G. Herpes simplex virus: Receptors and ligands for cell entry. Cell Microbiol. 2004, 6, 401-410. [CrossRef] [PubMed]

85. Tiwari, V.; Tarbutton, M.S.; Shukla, D. Diversity of heparan sulfate and HSV entry: Basic understanding and treatment strategies. Molecules 2015, 20, 2707-2727. [CrossRef] [PubMed]

86. Akhtar, J.; Shukla, D. Viral entry mechanisms: Cellular and viral mediators of herpes simplex virus entry. FEBS J. 2009, 276, 7228-7236. [CrossRef] [PubMed]

87. Tiwari, V.; Clement, C.; Xu, D.; Valyi-Nagy, T.; Yue, B.Y.; Liu, J.; Shukla, D. Role for 3-O-sulfated heparan sulfate as the receptor for herpes simplex virus type 1 entry into primary human corneal fibroblasts. J. Virol. 2006, 80, 8970-8980. [CrossRef] [PubMed]

88. Tiwari, V.; O’Donnell, C.; Copeland, R.J.; Scarlett, T.; Liu, J.; Shukla, D. Soluble 3-O-sulfated heparan sulfate can trigger herpes simplex virus type 1 entry into resistant Chinese hamster ovary (CHO-K1) cells. J. Gen. Virol. 2007, 88, 1075-1079. [CrossRef] [PubMed]

89. Agelidis, A.M.; Shukla, D. Cell entry mechanisms of HSV: What we have learned in recent years. Future Virol. 2015, 10, 1145-1154. [CrossRef]

90. Hadigal, S.R.; Agelidis, A.M.; Karasneh, G.A.; Antoine, T.E.; Yakoub, A.M.; Ramani, V.C.; Djalilian, A.R.; Sanderson, R.D.; Shukla, D. Heparanase is a host enzyme required for herpes simplex virus-1 release from cells. Nat. Commun. 2015, 6, 6985. [CrossRef] 
91. Hopkins, J.; Yadavalli, T.; Agelidis, A.M.; Shukla, D. Host Enzymes Heparanase and Cathepsin L Promote Herpes Simplex Virus 2 Release from Cells. J. Virol. 2018, 92. [CrossRef]

92. Cagno, V.; Andreozzi, P.; D’Alicarnasso, M.; Jacob Silva, P.; Mueller, M.; Galloux, M.; Le Goffic, R.; Jones, S.T.; Vallino, M.; Hodek, J.; et al. Broad-spectrum non-toxic antiviral nanoparticles with a virucidal inhibition mechanism. Nat. Mater. 2018, 17, 195-203. [CrossRef]

93. Donalisio, M.; Quaranta, P.; Chiuppesi, F.; Pistello, M.; Cagno, V.; Cavalli, R.; Volante, M.; Bugatti, A.; Rusnati, M.; Ranucci, E.; et al. The AGMA1 poly(amidoamine) inhibits the infectivity of herpes simplex virus in cell lines, in human cervicovaginal histocultures, and in vaginally infected mice. Biomaterials 2016, 85, 40-53. [CrossRef] [PubMed]

94. Schmidtke, M.; Karger, A.; Meerbach, A.; Egerer, R.; Stelzner, A.; Makarov, V. Binding of a N,N'-bisheteryl derivative of dispirotripiperazine to heparan sulfate residues on the cell surface specifically prevents infection of viruses from different families. Virology 2003, 311, 134-143. [CrossRef]

95. Anderson, R.A.; Feathergill, K.A.; Diao, X.H.; Cooper, M.D.; Kirkpatrick, R.; Herold, B.C.; Doncel, G.F.; Chany, C.J.; Waller, D.P.; Rencher, W.F.; et al. Preclinical evaluation of sodium cellulose sulfate (Ushercell) as a contraceptive antimicrobial agent. J. Androl. 2002, 23, 426-438. [PubMed]

96. Keller, M.J.; Zerhouni-Layachi, B.; Cheshenko, N.; John, M.; Hogarty, K.; Kasowitz, A.; Goldberg, C.L.; Wallenstein, S.; Profy, A.T.; Klotman, M.E.; et al. PRO 2000 gel inhibits HIV and herpes simplex virus infection following vaginal application: A double-blind placebo-controlled trial. J. Infect. Dis 2006, 193, 27-35. [CrossRef] [PubMed]

97. Cheshenko, N.; Keller, M.J.; MasCasullo, V.; Jarvis, G.A.; Cheng, H.; John, M.; Li, J.H.; Hogarty, K.; Anderson, R.A.; Waller, D.P.; et al. Candidate topical microbicides bind herpes simplex virus glycoprotein B and prevent viral entry and cell-to-cell spread. Antimicrob. Agents Chemother. 2004, 48, 2025-2036. [CrossRef] [PubMed]

98. Luganini, A.; Giuliani, A.; Pirri, G.; Pizzuto, L.; Landolfo, S.; Gribaudo, G. Peptide-derivatized dendrimers inhibit human cytomegalovirus infection by blocking virus binding to cell surface heparan sulfate. Antivir. Res. 2010, 85, 532-540. [CrossRef] [PubMed]

99. Price, C.F.; Tyssen, D.; Sonza, S.; Davie, A.; Evans, S.; Lewis, G.R.; Xia, S.; Spelman, T.; Hodsman, P.; Moench, T.R.; et al. SPL7013 Gel (VivaGel(R)) retains potent HIV-1 and HSV-2 inhibitory activity following vaginal administration in humans. PLoS ONE 2011, 6, e24095. [CrossRef]

100. Pinna, D.; Oreste, P.; Coradin, T.; Kajaste-Rudnitski, A.; Ghezzi, S.; Zoppetti, G.; Rotola, A.; Argnani, R.; Poli, G.; Manservigi, R.; et al. Inhibition of herpes simplex virus types 1 and 2 in vitro infection by sulfated derivatives of Escherichia coli K5 polysaccharide. Antimicrob. Agents Chemother. 2008, 52, 3078-3084. [CrossRef]

101. Vervaeke, P.; Alen, M.; Noppen, S.; Schols, D.; Oreste, P.; Liekens, S. Sulfated Escherichia coli K5 polysaccharide derivatives inhibit dengue virus infection of human microvascular endothelial cells by interacting with the viral envelope protein E domain III. PLoS ONE 2013, 8, e74035. [CrossRef]

102. Talarico, L.B.; Damonte, E.B. Interference in dengue virus adsorption and uncoating by carrageenans. Virology 2007, 363, 473-485. [CrossRef]

103. Mercorelli, B.; Oreste, P.; Sinigalia, E.; Muratore, G.; Lembo, D.; Palu, G.; Loregian, A. Sulfated derivatives of Escherichia coli K5 capsular polysaccharide are potent inhibitors of human cytomegalovirus. Antimicrob. Agents Chemother. 2010, 54, 4561-4567. [CrossRef] [PubMed]

104. Donalisio, M.; Ranucci, E.; Cagno, V.; Civra, A.; Manfredi, A.; Cavalli, R.; Ferruti, P.; Lembo, D. Agmatine-containing poly(amidoamine)s as a novel class of antiviral macromolecules: Structural properties and in vitro evaluation of infectivity inhibition. Antimicrob. Agents Chemother. 2014, 58, 6315-6319. [CrossRef] [PubMed]

105. Buck, C.B.; Thompson, C.D.; Roberts, J.N.; Muller, M.; Lowy, D.R.; Schiller, J.T. Carrageenan is a potent inhibitor of papillomavirus infection. PLoS Pathog. 2006, 2, e69. [CrossRef] [PubMed]

106. Skoler-Karpoff, S.; Ramjee, G.; Ahmed, K.; Altini, L.; Plagianos, M.G.; Friedland, B.; Govender, S.; De Kock, A.; Cassim, N.; Palanee, T.; et al. Efficacy of Carraguard for prevention of HIV infection in women in South Africa: A randomised, double-blind, placebo-controlled trial. Lancet 2008, 372, 1977-1987. [CrossRef]

107. Pirrone, V.; Wigdahl, B.; Krebs, F.C. The rise and fall of polyanionic inhibitors of the human immunodeficiency virus type 1. Antivir. Res. 2011, 90, 168-182. [CrossRef] [PubMed] 
108. Magnan, S.; Tota, J.E.; El-Zein, M.; Burchell, A.N.; Schiller, J.T.; Ferenczy, A.; Tellier, P.P.; Coutlee, F.; Franco, E.L.; Group, C.S. Efficacy of a Carrageenan gel Against Transmission of Cervical HPV (CATCH): Interim analysis of a randomized, double-blind, placebo-controlled, phase 2B trial. Clin. Microbiol. Infect. 2018. [CrossRef] [PubMed]

109. Rodriguez, A.; Kleinbeck, K.; Mizenina, O.; Kizima, L.; Levendosky, K.; Jean-Pierre, N.; Villegas, G.; Ford, B.E.; Cooney, M.L.; Teleshova, N.; et al. In vitro and in vivo evaluation of two carrageenan-based formulations to prevent HPV acquisition. Antivir. Res. 2014, 108, 88-93. [CrossRef] [PubMed]

110. Halpern, V.; Ogunsola, F.; Obunge, O.; Wang, C.H.; Onyejepu, N.; Oduyebo, O.; Taylor, D.; McNeil, L.; Mehta, N.; Umo-Otong, J.; et al. Effectiveness of cellulose sulfate vaginal gel for the prevention of HIV infection: Results of a Phase III trial in Nigeria. PLoS ONE 2008, 3, e3784. [CrossRef]

111. Christensen, N.D.; Reed, C.A.; Culp, T.D.; Hermonat, P.L.; Howett, M.K.; Anderson, R.A.; Zaneveld, L.J. Papillomavirus microbicidal activities of high-molecular-weight cellulose sulfate, dextran sulfate, and polystyrene sulfonate. Antimicrob. Agents Chemother. 2001, 45, 3427-3432. [CrossRef]

112. Donalisio, M.; Rusnati, M.; Civra, A.; Bugatti, A.; Allemand, D.; Pirri, G.; Giuliani, A.; Landolfo, S.; Lembo, D. Identification of a dendrimeric heparan sulfate-binding peptide that inhibits infectivity of genital types of human papillomaviruses. Antimicrob. Agents Chemother. 2010, 54, 4290-4299. [CrossRef]

113. Lembo, D.; Donalisio, M.; Rusnati, M.; Bugatti, A.; Cornaglia, M.; Cappello, P.; Giovarelli, M.; Oreste, P.; Landolfo, S. Sulfated K5 Escherichia coli polysaccharide derivatives as wide-range inhibitors of genital types of human papillomavirus. Antimicrob. Agents Chemother. 2008, 52, 1374-1381. [CrossRef] [PubMed]

114. Bon, I.; Lembo, D.; Rusnati, M.; Clo, A.; Morini, S.; Miserocchi, A.; Bugatti, A.; Grigolon, S.; Musumeci, G.; Landolfo, S. Peptide-derivatized SB105-A10 dendrimer inhibits the infectivity of R5 and X4 HIV-1 strains in primary PBMCs and cervicovaginal histocultures. PLoS ONE 2013, 8, e76482. [CrossRef] [PubMed]

115. Cagno, V.; Donalisio, M.; Bugatti, A.; Civra, A.; Cavalli, R.; Ranucci, E.; Ferruti, P.; Rusnati, M.; Lembo, D. The agmatine-containing poly(amidoamine) polymer AGMA1 binds cell surface heparan sulfates and prevents attachment of mucosal human papillomaviruses. Antimicrob. Agents Chemother. 2015, 59, 5250-5259. [CrossRef] [PubMed]

116. Pacciarini, F.; Ghezzi, S.; Pinna, D.; Cima, S.; Zoppetti, G.; Oreste, P.; Poli, G.; Vicenzi, E. Sulfated K5 Escherichia coli polysaccharide derivatives inhibit human immunodeficiency type-1 (HIV-1) infection: Candidate microbicides to prevent sexual HIV transmission. New Microbiol. 2004, 27, 5-9. [PubMed]

117. Selinka, H.C.; Florin, L.; Patel, H.D.; Freitag, K.; Schmidtke, M.; Makarov, V.A.; Sapp, M. Inhibition of transfer to secondary receptors by heparan sulfate-binding drug or antibody induces noninfectious uptake of human papillomavirus. J. Virol. 2007, 81, 10970-10980. [CrossRef] [PubMed]

118. Hallak, L.K.; Spillmann, D.; Collins, P.L.; Peeples, M.E. Glycosaminoglycan sulfation requirements for respiratory syncytial virus infection. J. Virol. 2000, 74, 10508-10513. [CrossRef]

119. Thammawat, S.; Sadlon, T.A.; Hallsworth, P.G.; Gordon, D.L. Role of cellular glycosaminoglycans and charged regions of viral G protein in human metapneumovirus infection. J. Virol. 2008, 82, 11767-11774. [CrossRef]

120. Chiu, Y.H.; Chan, Y.L.; Tsai, L.W.; Li, T.L.; Wu, C.J. Prevention of human enterovirus 71 infection by kappa carrageenan. Antivir. Res. 2012, 95, 128-134. [CrossRef]

121. Culp, T.D.; Budgeon, L.R.; Marinkovich, M.P.; Meneguzzi, G.; Christensen, N.D. Keratinocyte-secreted laminin 5 can function as a transient receptor for human papillomaviruses by binding virions and transferring them to adjacent cells. J. Virol. 2006, 80, 8940-8950. [CrossRef]

122. Surviladze, Z.; Sterkand, R.T.; Ozbun, M.A. Interaction of human papillomavirus type 16 particles with heparan sulfate and syndecan-1 molecules in the keratinocyte extracellular matrix plays an active role in infection. J. Gen. Virol 2015, 96, 2232-2241. [CrossRef]

123. Horvath, C.A.; Boulet, G.A.; Renoux, V.M.; Delvenne, P.O.; Bogers, J.P. Mechanisms of cell entry by human papillomaviruses: An overview. Virol J. 2010, 7, 11. [CrossRef] [PubMed]

124. Shafti-Keramat, S.; Handisurya, A.; Kriehuber, E.; Meneguzzi, G.; Slupetzky, K.; Kirnbauer, R. Different heparan sulfate proteoglycans serve as cellular receptors for human papillomaviruses. J. Virol. 2003, 77, 13125-13135. [CrossRef] [PubMed]

125. Johnson, K.M.; Kines, R.C.; Roberts, J.N.; Lowy, D.R.; Schiller, J.T.; Day, P.M. Role of heparan sulfate in attachment to and infection of the murine female genital tract by human papillomavirus. J. Virol. 2009, 83, 2067-2074. [CrossRef] [PubMed] 
126. Richards, K.F.; Bienkowska-Haba, M.; Dasgupta, J.; Chen, X.S.; Sapp, M. Multiple heparan sulfate binding site engagements are required for the infectious entry of human papillomavirus type 16. J. Virol. 2013, 87, 11426-11437. [CrossRef] [PubMed]

127. Bienkowska-Haba, M.; Patel, H.D.; Sapp, M. Target cell cyclophilins facilitate human papillomavirus type 16 infection. PLoS Pathog. 2009, 5, e1000524. [CrossRef] [PubMed]

128. Richards, R.M.; Lowy, D.R.; Schiller, J.T.; Day, P.M. Cleavage of the papillomavirus minor capsid protein, L2, at a furin consensus site is necessary for infection. Proc. Natl. Acad. Sci. USA 2006, 103, 1522-1527. [CrossRef] [PubMed]

129. Raff, A.B.; Woodham, A.W.; Raff, L.M.; Skeate, J.G.; Yan, L.; Da Silva, D.M.; Schelhaas, M.; Kast, W.M. The evolving field of human papillomavirus receptor research: A review of binding and entry. J. Virol. 2013, 87, 6062-6072. [CrossRef] [PubMed]

130. Becker, M.; Greune, L.; Schmidt, M.A.; Schelhaas, M. Extracellular conformational changes in the capsid of human papillomaviruses contribute to asynchronous uptake into host cells. J. Virol. 2018. [CrossRef] [PubMed]

131. Spoden, G.; Kuhling, L.; Cordes, N.; Frenzel, B.; Sapp, M.; Boller, K.; Florin, L.; Schelhaas, M. Human papillomavirus types 16, 18, and 31 share similar endocytic requirements for entry. J. Virol. 2013, 87, 7765-7773. [CrossRef] [PubMed]

132. Marais, D.; Gawarecki, D.; Allan, B.; Ahmed, K.; Altini, L.; Cassim, N.; Gopolang, F.; Hoffman, M.; Ramjee, G.; Williamson, A.L. The effectiveness of Carraguard, a vaginal microbicide, in protecting women against high-risk human papillomavirus infection. Antivir. Ther. 2011, 16, 1219-1226. [CrossRef]

133. Bhatt, S.; Gething, P.W.; Brady, O.J.; Messina, J.P.; Farlow, A.W.; Moyes, C.L.; Drake, J.M.; Brownstein, J.S.; Hoen, A.G.; Sankoh, O.; et al. The global distribution and burden of dengue. Nature 2013, 496, 504-507. [CrossRef] [PubMed]

134. Chen, Y.; Maguire, T.; Hileman, R.E.; Fromm, J.R.; Esko, J.D.; Linhardt, R.J.; Marks, R.M. Dengue virus infectivity depends on envelope protein binding to target cell heparan sulfate. Nat. Med. 1997, 3, 866-871. [CrossRef] [PubMed]

135. Hung, J.J.; Hsieh, M.T.; Young, M.J.; Kao, C.L.; King, C.C.; Chang, W. An external loop region of domain III of dengue virus type 2 envelope protein is involved in serotype-specific binding to mosquito but not mammalian cells. J. Virol. 2004, 78, 378-388. [CrossRef] [PubMed]

136. Dalrymple, N.; Mackow, E.R. Productive dengue virus infection of human endothelial cells is directed by heparan sulfate-containing proteoglycan receptors. J. Virol. 2011, 85, 9478-9485. [CrossRef] [PubMed]

137. Germi, R.; Crance, J.M.; Garin, D.; Guimet, J.; Lortat-Jacob, H.; Ruigrok, R.W.; Zarski, J.P.; Drouet, E. Heparan sulfate-mediated binding of infectious dengue virus type 2 and yellow fever virus. Virology 2002, 292, 162-168. [CrossRef] [PubMed]

138. Hilgard, P.; Stockert, R. Heparan sulfate proteoglycans initiate dengue virus infection of hepatocytes. Hepatology 2000, 32, 1069-1077. [CrossRef] [PubMed]

139. Talarico, L.B.; Pujol, C.A.; Zibetti, R.G.; Faria, P.C.; Noseda, M.D.; Duarte, M.E.; Damonte, E.B. The antiviral activity of sulfated polysaccharides against dengue virus is dependent on virus serotype and host cell. Antivir. Res. 2005, 66, 103-110. [CrossRef] [PubMed]

140. Acosta, E.G.; Piccini, L.E.; Talarico, L.B.; Castilla, V.; Damonte, E.B. Changes in antiviral susceptibility to entry inhibitors and endocytic uptake of dengue-2 virus serially passaged in Vero or C6/36 cells. Virus Res. 2014, 184, 39-43. [CrossRef]

141. Cruz-Oliveira, C.; Freire, J.M.; Conceicao, T.M.; Higa, L.M.; Castanho, M.A.; Da Poian, A.T. Receptors and routes of dengue virus entry into the host cells. Fems Microbiol. Rev. 2015, 39, 155-170. [CrossRef]

142. Gwaltney, J.M. Clinical significance and pathogenesis of viral respiratory infections. Am. J. Med. 2002, 112 Suppl. 6A, 13S-18S. [CrossRef]

143. Edwards, M.R.; Bartlett, N.W.; Hussell, T.; Openshaw, P.; Johnston, S.L. The microbiology of asthma. Nat. Rev. Microbiol 2012, 10, 459-471. [CrossRef] [PubMed]

144. Gern, J.E. The ABCs of rhinoviruses, wheezing, and asthma. J. Virol. 2010, 84, 7418-7426. [CrossRef] [PubMed]

145. Kherad, O.; Kaiser, L.; Bridevaux, P.O.; Sarasin, F.; Thomas, Y.; Janssens, J.P.; Rutschmann, O.T. Upper-respiratory viral infection, biomarkers, and COPD exacerbations. Chest 2010, 138, 896-904. [CrossRef] [PubMed] 
146. Seemungal, T.A.; Harper-Owen, R.; Bhowmik, A.; Jeffries, D.J.; Wedzicha, J.A. Detection of rhinovirus in induced sputum at exacerbation of chronic obstructive pulmonary disease. Eur. Respir. J. 2000, 16, 677-683. [CrossRef] [PubMed]

147. Renwick, N.; Schweiger, B.; Kapoor, V.; Liu, Z.; Villari, J.; Bullmann, R.; Miething, R.; Briese, T.; Lipkin, W.I. A recently identified rhinovirus genotype is associated with severe respiratory-tract infection in children in Germany. J. Infect. Dis. 2007, 196, 1754-1760. [CrossRef] [PubMed]

148. Kaiser, L.; Aubert, J.D.; Pache, J.C.; Deffernez, C.; Rochat, T.; Garbino, J.; Wunderli, W.; Meylan, P.; Yerly, S.; Perrin, L.; et al. Chronic rhinoviral infection in lung transplant recipients. Am. J. Respir. Crit. Care Med. 2006, 174, 1392-1399. [CrossRef]

149. Tapparel, C.; Cordey, S.; Junier, T.; Farinelli, L.; Van Belle, S.; Soccal, P.M.; Aubert, J.D.; Zdobnov, E.; Kaiser, L. Rhinovirus genome variation during chronic upper and lower respiratory tract infections. PLoS ONE 2011, 6, e21163. [CrossRef]

150. Uncapher, C.R.; DeWitt, C.M.; Colonno, R.J. The major and minor group receptor families contain all but one human rhinovirus serotype. Virology 1991, 180, 814-817. [CrossRef]

151. Hofer, F.; Gruenberger, M.; Kowalski, H.; Machat, H.; Huettinger, M.; Kuechler, E.; Blass, D. Members of the low density lipoprotein receptor family mediate cell entry of a minor-group common cold virus. Proc. Natl. Acad. Sci. USA 1994, 91, 1839-1842. [CrossRef]

152. Bochkov, Y.A.; Watters, K.; Ashraf, S.; Griggs, T.F.; Devries, M.K.; Jackson, D.J.; Palmenberg, A.C.; Gern, J.E. Cadherin-related family member 3 , a childhood asthma susceptibility gene product, mediates rhinovirus $\mathrm{C}$ binding and replication. Proc. Natl. Acad. Sci. USA 2015, 112, 5485-5490. [CrossRef]

153. Griggs, T.F.; Bochkov, Y.A.; Basnet, S.; Pasic, T.R.; Brockman-Schneider, R.A.; Palmenberg, A.C.; Gern, J.E. Rhinovirus C targets ciliated airway epithelial cells. Respir. Res. 2017, 18, 84. [CrossRef] [PubMed]

154. Zautner, A.E.; Korner, U.; Henke, A.; Badorff, C.; Schmidtke, M. Heparan sulfates and coxsackievirus-adenovirus receptor: Each one mediates coxsackievirus B3 PD infection. J. Virol. 2003, 77, 10071-10077. [CrossRef]

155. World Health Organization (WHO). A Guide to Clinical Management and Public Health Response for Hand, Foot and Mouth Disease (HFMD). WHO Libr. Cat. Publ. Data 2011, 18.

156. Chan, L.G.; Parashar, U.D.; Lye, M.S.; Ong, F.G.L.; Zaki, S.R.; Alexander, J.P.; Ho, K.K.; Han, L.L.; Pallansch, M.A.; Suleiman, A.B.; et al. Deaths of children during an outbreak of hand, foot, and mouth disease in Sarawak, Malaysia: Clinical and pathological characteristics of the disease. Clin. Infect. Dis. 2000, 31, 678-683. [CrossRef] [PubMed]

157. Chang, L.Y. Enterovirus 71 in Taiwan. Pediatr. Neonatol. 2008, 49, 103-112. [CrossRef]

158. Qiu, J. Enterovirus 71 infection: A new threat to global public health? Lancet Neurol. 2008, 7, 868-869. [CrossRef]

159. Ooi, M.H.; Wong, S.C.; Lewthwaite, P.; Cardosa, M.J.; Solomon, T. Clinical features, diagnosis, and management of enterovirus 71. Lancet Neurol. 2010, 9, 1097-1105. [CrossRef]

160. McMinn, P.C. An overview of the evolution of enterovirus 71 and its clinical and public health significance. Fems Microbiol. Rev. 2002, 26, 91-107. [CrossRef]

161. Yi, E.J.; Shin, Y.J.; Kim, J.H.; Kim, T.G.; Chang, S.Y. Enterovirus 71 infection and vaccines. Clin. Exp. Vaccine Res. 2017, 6, 4-14. [CrossRef]

162. Yamayoshi, S.; Yamashita, Y.; Li, J.; Hanagata, N.; Minowa, T.; Takemura, T.; Koike, S. Scavenger receptor B2 is a cellular receptor for enterovirus 71. Nat. Med. 2009, 15, 798-801. [CrossRef]

163. Nishimura, Y.; Lee, H.; Hafenstein, S.; Kataoka, C.; Wakita, T.; Bergelson, J.M.; Shimizu, H. Enterovirus 71 binding to PSGL-1 on leukocytes: VP1-145 acts as a molecular switch to control receptor interaction. PLoS Pathog. 2013, 9, e1003511. [CrossRef] [PubMed]

164. Nishimura, Y.; Shimojima, M.; Tano, Y.; Miyamura, T.; Wakita, T.; Shimizu, H. Human P-selectin glycoprotein ligand-1 is a functional receptor for enterovirus 71. Nat. Med. 2009, 15, 794-797. [CrossRef] [PubMed]

165. Yang, B.; Chuang, H.; Yang, K.D. Sialylated glycans as receptor and inhibitor of enterovirus 71 infection to DLD-1 intestinal cells. Virol. J. 2009, 6, 141. [CrossRef] [PubMed]

166. Su, P.Y.; Wang, Y.F.; Huang, S.W.; Lo, Y.C.; Wang, Y.H.; Wu, S.R.; Shieh, D.B.; Chen, S.H.; Wang, J.R.; Lai, M.D.; et al. Cell surface nucleolin facilitates enterovirus 71 binding and infection. J. Virol. 2015, 89, 4527-4538. [CrossRef] [PubMed]

167. Du, N.; Cong, H.; Tian, H.; Zhang, H.; Zhang, W.; Song, L.; Tien, P. Cell surface vimentin is an attachment receptor for enterovirus 71. J. Virol. 2014, 88, 5816-5833. [CrossRef] [PubMed] 
168. Yang, S.L.; Chou, Y.T.; Wu, C.N.; Ho, M.S. Annexin II binds to capsid protein VP1 of enterovirus 71 and enhances viral infectivity. J. Virol. 2011, 85, 11809-11820. [CrossRef]

169. DeCaprio, J.A.; Garcea, R.L. A cornucopia of human polyomaviruses. Nat. Rev. Microbiol 2013, 11, $264-276$. [CrossRef]

170. Liu, W.; MacDonald, M.; You, J. Merkel cell polyomavirus infection and Merkel cell carcinoma. Curr. Opin. Virol. 2016, 20, 20-27. [CrossRef]

171. Neu, U.; Maginnis, M.S.; Palma, A.S.; Stroh, L.J.; Nelson, C.D.; Feizi, T.; Atwood, W.J.; Stehle, T. Structure-function analysis of the human JC polyomavirus establishes the LSTc pentasaccharide as a functional receptor motif. Cell Host Microbe 2010, 8, 309-319. [CrossRef]

172. Maginnis, M.S.; Haley, S.A.; Gee, G.V.; Atwood, W.J. Role of N-linked glycosylation of the 5-HT2A receptor in JC virus infection. J. Virol. 2010, 84, 9677-9684. [CrossRef]

173. Gorelik, L.; Reid, C.; Testa, M.; Brickelmaier, M.; Bossolasco, S.; Pazzi, A.; Bestetti, A.; Carmillo, P.; Wilson, E.; McAuliffe, M.; et al. Progressive multifocal leukoencephalopathy (PML) development is associated with mutations in JC virus capsid protein VP1 that change its receptor specificity. J. Infect. Dis 201, 204, 103-114. [CrossRef] [PubMed]

174. Shi, T.; McAllister, D.A.; O’Brien, K.L.; Simoes, E.A.F.; Madhi, S.A.; Gessner, B.D.; Polack, F.P.; Balsells, E.; Acacio, S.; Aguayo, C.; et al. Global, regional, and national disease burden estimates of acute lower respiratory infections due to respiratory syncytial virus in young children in 2015: A systematic review and modelling study. Lancet 2017, 390, 946-958. [CrossRef]

175. Johnson, S.; Oliver, C.; Prince, G.A.; Hemming, V.G.; Pfarr, D.S.; Wang, S.C.; Dormitzer, M.; O'Grady, J.; Koenig, S.; Tamura, J.K.; et al. Development of a humanized monoclonal antibody (MEDI-493) with potent in vitro and in vivo activity against respiratory syncytial virus. J. Infect. Dis 1997, 176, 1215-1224. [CrossRef] [PubMed]

176. American Academy of Pediatrics Committee on Infectious Diseases; American Academy of Pediatrics Bronchiolitis Guidelines Committee. Updated guidance for palivizumab prophylaxis among infants and young children at increased risk of hospitalization for respiratory syncytial virus infection. Pediatrics 2014, 134, 415-420. [CrossRef] [PubMed]

177. Crim, R.L.; Audet, S.A.; Feldman, S.A.; Mostowski, H.S.; Beeler, J.A. Identification of linear heparin-binding peptides derived from human respiratory syncytial virus fusion glycoprotein that inhibit infectivity. J. Virol. 2007, 81, 261-271. [CrossRef] [PubMed]

178. Feldman, S.A.; Audet, S.; Beeler, J.A. The fusion glycoprotein of human respiratory syncytial virus facilitates virus attachment and infectivity via an interaction with cellular heparan sulfate. J. Virol. 2000, 74, 6442-6447. [CrossRef] [PubMed]

179. Feldman, S.A.; Hendry, R.M.; Beeler, J.A. Identification of a linear heparin binding domain for human respiratory syncytial virus attachment glycoprotein G. J. Virol. 1999, 73, 6610-6617.

180. Tayyari, F.; Marchant, D.; Moraes, T.J.; Duan, W.; Mastrangelo, P.; Hegele, R.G. Identification of nucleolin as a cellular receptor for human respiratory syncytial virus. Nat. Med. 2011, 17, 1132-1135. [CrossRef]

181. Behera, A.K.; Matsuse, H.; Kumar, M.; Kong, X.; Lockey, R.F.; Mohapatra, S.S. Blocking intercellular adhesion molecule-1 on human epithelial cells decreases respiratory syncytial virus infection. Biochem. Biophys. Res. Commun. 2001, 280, 188-195. [CrossRef]

182. Harcourt, J.; Alvarez, R.; Jones, L.P.; Henderson, C.; Anderson, L.J.; Tripp, R.A. Respiratory syncytial virus $\mathrm{G}$ protein and $\mathrm{G}$ protein CX3C motif adversely affect CX3CR1+ T cell responses. J. Immunol. 2006, 176, 1600-1608. [CrossRef]

183. Malhotra, R.; Ward, M.; Bright, H.; Priest, R.; Foster, M.R.; Hurle, M.; Blair, E.; Bird, M. Isolation and characterisation of potential respiratory syncytial virus receptor(s) on epithelial cells. Microbes Infect. 2003, 5, 123-133. [CrossRef]

184. Gilman, M.S.; Moin, S.M.; Mas, V.; Chen, M.; Patel, N.K.; Kramer, K.; Zhu, Q.; Kabeche, S.C.; Kumar, A.; Palomo, C.; et al. Characterization of a Prefusion-Specific Antibody That Recognizes a Quaternary, Cleavage-Dependent Epitope on the RSV Fusion Glycoprotein. PLoS Pathog. 2015, 11, e1005035. [CrossRef] [PubMed]

185. Chirkova, T.; Lin, S.; Oomens, A.G.; Gaston, K.A.; Boyoglu-Barnum, S.; Meng, J.; Stobart, C.C.; Cotton, C.U.; Hartert, T.V.; Moore, M.L.; et al. CX3CR1 is an important surface molecule for respiratory syncytial virus infection in human airway epithelial cells. J. Gen. Virol. 2015, 96, 2543-2556. [CrossRef] [PubMed] 
186. Haeger, S.M.; Liu, X.; Han, X.; McNeil, J.B.; Oshima, K.; McMurtry, S.A.; Yang, Y.; Ouyang, Y.; Zhang, F.; Nozik-Grayck, E.; et al. Epithelial Heparan Sulfate Contributes to Alveolar Barrier Function and Is Shed during Lung Injury. Am. J. Respir. Cell Mol. Biol. 2018, 59, 363-374. [CrossRef] [PubMed]

187. Pierson, T.C.; Diamond, M.S. The emergence of Zika virus and its new clinical syndromes. Nature 2018, 560, 573-581. [CrossRef] [PubMed]

188. Kim, S.Y.; Koetzner, C.A.; Payne, A.F.; Nierode, G.J.; Yu, Y.; Wang, R.; Barr, E.; Dordick, J.S.; Kramer, L.D.; Zhang, F.; et al. Glycosaminoglycan Compositional Analysis of Relevant Tissues in Zika Virus Pathogenesis and in Vitro Evaluation of Heparin as an Antiviral against Zika Virus Infection. Biochemistry 2019, 58, 1155-1166. [CrossRef] [PubMed]

189. Van Boheemen, S.; Tas, A.; Anvar, S.Y.; van Grootveld, R.; Albulescu, I.C.; Bauer, M.P.; Feltkamp, M.C.; Bredenbeek, P.J.; van Hemert, M.J. Quasispecies composition and evolution of a typical Zika virus clinical isolate from Suriname. Sci. Rep. 2017, 7, 2368. [CrossRef] [PubMed]

190. Gao, H.; Lin, Y.; He, J.; Zhou, S.; Liang, M.; Huang, C.; Li, X.; Liu, C.; Zhang, P. Role of heparan sulfate in the Zika virus entry, replication, and cell death. Virology 2019, 529, 91-100. [CrossRef]

191. Bobardt, M.D.; Salmon, P.; Wang, L.; Esko, J.D.; Gabuzda, D.; Fiala, M.; Trono, D.; Van der Schueren, B.; David, G.; Gallay, P.A. Contribution of proteoglycans to human immunodeficiency virus type 1 brain invasion. J. Virol. 2004, 78, 6567-6584. [CrossRef]

192. Ryman, K.D.; Gardner, C.L.; Burke, C.W.; Meier, K.C.; Thompson, J.M.; Klimstra, W.B. Heparan sulfate binding can contribute to the neurovirulence of neuroadapted and nonneuroadapted Sindbis viruses. J. Virol. 2007, 81, 3563-3573. [CrossRef]

193. Zhang, B.; Wu, X.; Huang, K.; Li, L.; Zheng, L.; Wan, C.; He, M.L.; Zhao, W. The variations of VP1 protein might be associated with nervous system symptoms caused by enterovirus 71 infection. BMC Infect. Dis. 2014, 14, 243. [CrossRef] [PubMed]

194. Fujii, K.; Sudaka, Y.; Takashino, A.; Kobayashi, K.; Kataoka, C.; Suzuki, T.; Iwata-Yoshikawa, N.; Kotani, O.; Ami, Y.; Shimizu, H.; et al. VP1 amino acid residue 145 of enterovirus 71 is a key residue for its receptor attachment and resistance to neutralizing antibody during cynomolgus monkey infection. J. Virol. 2018. [CrossRef] [PubMed]

195. Lee, E.; Lobigs, M. E protein domain III determinants of yellow fever virus 17D vaccine strain enhance binding to glycosaminoglycans, impede virus spread, and attenuate virulence. J. Virol. 2008, 82, 6024-6033. [CrossRef] [PubMed]

196. Prestwood, T.R.; Prigozhin, D.M.; Sharar, K.L.; Zellweger, R.M.; Shresta, S. A mouse-passaged dengue virus strain with reduced affinity for heparan sulfate causes severe disease in mice by establishing increased systemic viral loads. J. Virol. 2008, 82, 8411-8421. [CrossRef] [PubMed]

197. Seitz, S.; Iancu, C.; Volz, T.; Mier, W.; Dandri, M.; Urban, S.; Bartenschlager, R. A Slow Maturation Process Renders Hepatitis B Virus Infectious. Cell Host Microbe 2016, 20, 25-35. [CrossRef] 